NBER WORKING PAPER SERIES

\title{
TEN FACTS ON DECLINING BUSINESS DYNAMISM AND LESSONS FROM ENDOGENOUS GROWTH THEORY
}

\author{
Ufuk Akcigit \\ Sina T. Ates \\ Working Paper 25755 \\ http://www.nber.org/papers/w25755 \\ NATIONAL BUREAU OF ECONOMIC RESEARCH \\ 1050 Massachusetts Avenue \\ Cambridge, MA 02138 \\ April 2019
}

We thank seminar and conference participants at College de France, the 1st joint IMF-OECDWorld Bank conference on Structural Reforms, 7th CompNet Annual Conference, Bilkent University, and the Central Bank of the Republic of Turkey. Zhiyu Fu and Jeremy Pearce provided excellent research assistance. Akcigit gratefully acknowledges financial support from the National Science Foundation. The views in this paper are solely the responsibility of the authors and should not be interpreted as reflecting the views of the Board of Governors of the Federal Reserve System, nor of any other person associated with the Federal Reserve System, nor of the National Bureau of Economic Research.

NBER working papers are circulated for discussion and comment purposes. They have not been peer-reviewed or been subject to the review by the NBER Board of Directors that accompanies official NBER publications.

(C) 2019 by Ufuk Akcigit and Sina T. Ates. All rights reserved. Short sections of text, not to exceed two paragraphs, may be quoted without explicit permission provided that full credit, including $\odot$ notice, is given to the source. 
Ten Facts on Declining Business Dynamism and Lessons from Endogenous Growth Theory Ufuk Akcigit and Sina T. Ates

NBER Working Paper No. 25755

April 2019

JEL No. E22,K20,L10,L41,O33,O34

\begin{abstract}
In this paper, we review the literature on declining business dynamism and its implications in the United States and propose a unifying theory to analyze the symptoms and the potential causes of this decline. We first highlight 10 pronounced stylized facts related to declining business dynamism documented in the literature and discuss some of the existing attempts to explain them. We then describe a theoretical framework of endogenous markups, innovation, and competition that can potentially speak to all of these facts jointly. We next explore some theoretical predictions of this framework, which are shaped by two interacting forces: a "composition effect" that determines the market concentration and an "incentive effect" that determines how firms respond to a given concentration in the economy. The results highlight that a decline in "knowledge diffusion" between frontier and laggard firms could be a significant driver of empirical trends observed in the data. This study emphasizes the potential of growth theory for the analysis of factors behind declining business dynamism and the need for further investigation in this direction.
\end{abstract}

Ufuk Akcigit

Department of Economics

University of Chicago

1126 East 59th Street

Saieh Hall, Office 403

Chicago, IL 60637

and NBER

uakcigit@uchicago.edu

Sina T. Ates

Federal Reserve Board of Governors

20th \& C St.

Washington, DC 20551

sina.t.ates@frb.gov 


\section{Introduction}

Business dynamism in the United States has been slowing in the last several decades. Multiple studies have recently demonstrated various aspects of this declining U.S. business dynamism, some of which, interestingly, have also emerged in other economies. For example, the entry rate of new businesses has decreased, productivity growth has slowed down, the labor share of output has decreased, while market concentration and the corporate profit share of Gross Domestic Product (GDP) have increased. The literature has more or less agreed that there is a broad weakening of business dynamism in the United States. Yet, there is little agreement on the underlying causes of these empirical trends, and these trends have mostly been discussed in isolation. In a current research agenda, we strive to shed light on this discussion using new growth theory.

To better understand the drivers of declining U.S. business dynamism, we analyze the symptomatic empirical trends together in a unifying theoretical model that allows for the quantitative analysis of alternative explanations proposed in the literature. We conduct this analysis in two separate but complementary papers. In this one we focus on the empirical and theoretical aspects of the analysis. In particular, we first review a broad set of stylized facts documented in the literature. These facts are as follows. ${ }^{1}$

1. Market concentration has risen.

2. Average markups have increased.

3. Average profits have increased.

4. The labor share of output has gone down.

5. The rise in market concentration and the fall in labor share are positively associated.

6. The labor productivity gap between frontier and laggard firms has widened.

7. Firm entry rate has declined.

8. The share of young firms in economic activity has declined.

9. Job reallocation has slowed down.

10. The dispersion of firm growth has decreased.

Next, we propose a unifying theoretical framework to assess the plausibility of potential drivers of what has plagued the U.S. business environment. In particular, we demonstrate that the new theory of firm dynamics and endogenous growth proves especially useful in this regard.

\footnotetext{
${ }^{1}$ Many of these trends have also caught public attention, raising concerns that they may indicate a decline in business competition. The Economist has just published a special report on the subject matter [The Economist (2018c)]. Policymakers are also concerned. Indeed, the Federal Trade Commission has recently held the "Hearings on Competition and Consumer Protection in the $21^{\text {st }}$ Century" with special attention to competition and market concentration.
} 
Our analytical investigation shows that a fairly stylized version of a step-by-step innovation model of creative destruction and endogenous competition is capable of replicating salient features of declining business dynamism. Our analysis also demonstrates that the ramifications of endogenous growth theory continue to help us understand the intriguing aspects of business dynamics, underscoring the scope and the depth of this theory, which deservedly earned it this year's Nobel prize in economics.

The key ingredient of our model is the strategic interaction between two competing firms in each market. Our theoretical framework draws on the research and development $(\mathrm{R} \& \mathrm{D})$ race models of the industrial organizations literature [e.g., Harris and Vickers $(1985,1987)$, Budd et al. (1993)], where typically two players race for a prize and players exert different efforts depending on their own position relative to their competitors. A fruitful branch of endogenous growth literature has introduced these partial equilibrium models into a macro general equilibrium setting to study various aspects of product market competition with strategic interaction between competing firms [e.g., Aghion et al. (1997, 2001, 2005), Acemoglu and Akcigit (2012), Akcigit et al. (2018)]. Similar to these studies, our theoretical framework centers on an economy that consists of a measure of intermediate product lines. In each of these lines, two incumbent firms compete à la Bertrand for market leadership. ${ }^{2}$ These firms produce the same good with different labor productivities; hence, the firm that has a better technology serves the market. Sectors are of two types. In leveled sectors, both firms have the same productivity and, therefore, both firms have the same market share and competition is strongest. In unleveled sectors, one of the two firms has a strictly higher productivity and serves the entire market; hence, market concentration is highest. Crucially, in this model, the markups are endogenous. More specifically, the markup the leader firm can charge, and thus its profits, depends on the technological edge it has over its competitor. Firms invest in R\&D to improve their productivity, hoping to obtain market leadership or increase their profits. The key benefit of this framework is that it explicitly models the relationship between product market competition and firms' endogenous innovation decisions. While the strength of competition affects firms' innovation efforts, the technological advantage of a firm determines its relative position to its rival and thus its markup and profits. Therefore, this framework allows us to explore different margins that could have distorted firm-level decisions and thus have led to endogenous changes in business dynamism.

For the sake of exposition, in this paper we present a fairly standard version of the model, where we abstract from entry and limit the technology gaps the firms can potentially have. This comes with a big advantage: We are able to analytically derive theoretical predictions that

\footnotetext{
2 This framework emphasizes the crux of competition between firms-their strategic behavior. Strategic firm behavior creates a complex state space of firm decisions, as each of these depend on the decisions of other firms. The model overcomes this complexity by summarizing the web of strategic actions by the decisions of only two firms-a leader and the follower. These two firms stand for the best firm versus the rest of the firms in an industry. Therefore, the structure should not be interpreted as reflective of competition between only two firms; rather, it summarizes the competition between a market leader and the rest of firms, which strategically invest in innovative activities with the aim of overtaking the leader.
} 
illustrate most of the stylized facts, although at the expense of remaining silent on a few other ones. A crucial margin that we explore is knowledge diffusion between frontier and laggard firms. In the model, we include an exogenous probability of catch-up, which makes the laggard close its technology difference with the leader. This feature can be considered as a reduced-form representation of any mechanism that makes followers learn from leaders and a reduction of it leads to slower knowledge diffusion (e.g., due to more intense use intellectual property protection or firm-specific customer data). While such a spillover appears to be beneficial for laggard firms, in reality, it also entails a cost for the leading firm in terms of higher competition. In the model, this cost is reflected by the fact that the frontier firm loses its technology advantage and, thus, the leadership of the market.

We demonstrate theoretically that a decline in knowledge diffusion implies higher concentration with higher markups and profits, in line with empirical findings in the literature (Facts 1, 2 , and 3). It also generates a decrease in the labor share of output (Fact 4). The dominant force behind these results is the compositional shift in the economy to more unleveled and concentrated sectors where more productive firms pay less to their workers (Fact 5). As sectors become more concentrated, the productivity gap between the competing firms opens up (Fact 6). We also note that the lack of free entry of firms leaves our model agnostic about the age-related trends (Facts 7 and 8). Similarly, the combined variation in both the composition and incentive margins (affecting firms' innovation efforts) yields ambiguous results for other incumbent-growth related moments (Facts 9 and 10), calling for a quantitative investigation. Nevertheless, even though the simple theoretical analysis here falls short of replicating all stylized facts listed above, it demonstrates the potential of this framework to contribute to the discussion of declining business dynamism and shows that the reduction in knowledge diffusion may be a reason for the observed declining business dynamism. We leave a quantitative and more in-depth investigation (accounting for free entry of firms) to our complementary study Akcigit and Ates (2019).

The reason why we focus on the knowledge diffusion margin is twofold. First, Fact 6 suggests that there has been a divergence between productivity performance of frontier and laggard firms, with laggards falling behind even more in recent years. While this may be a symptom of a variety of causes, the empirical evidence discussed by Andrews et al. (2016) hints toward changes in the diffusion margin. Moreover, in our complementary study Akcigit and Ates (2019), we find that among competing alternative theories-changes in entry costs, corporate tax schemes, and $R \& D$ tax incentives - the decline in the intensity of knowledge diffusion is the only margin that can explain all observed trends both qualitatively and quantitatively. We also present some new empirical evidence that supports a slowdown in knowledge diffusion at the end of the paper.

While we explicitly focus on the declining U.S. business dynamism in this paper, we find it valuable to briefly discuss the model's implications for aggregate productivity growth. The balanced growth path of the model predicts an ambiguous effect of a decline in the intensity of knowledge diffusion on aggregate productivity growth, similar to Facts 9 and 10. Again, this 
result hinges on the combination of a positive incentive effect and a negative composition effect. However, the sequencing of these effects would matter if we consider the transition path of the economy adjusting to a decline in knowledge diffusion. While the initial stimulation of neckand-neck firms to innovate would raise the growth rate, the subsequent shift of the economy toward unleveled sectors would cause a growth decline, creating a hump-shaped response in aggregate productivity growth. This insight can shed a light on the recent "fast/slow" cycle observed in U.S. productivity growth-in other words, faster growth between roughly the mid1990s and mid-2000s, which many economists see as a byproduct of diffusion of information and communication technologies (ICT) in the economy, followed by a slower growth rate [Fernald (2014), Syverson (2017)].

The rest of the paper is structured as follows. Section 2 presents the empirical evidence on declining business dynamism. Section 3 discusses potential causes of these trends proposed in the literature. Section 4 presents the theoretical model and its analytical implications. Section 5 discusses the knowledge diffusion margin. Finally, Section 6 concludes.

\section{Empirical Trends in the United States}

In this section, we briefly discuss the empirical trends on which we focus throughout our analysis.

\section{Fact 1. Market Concentration Has Increased.}

Market concentration has been rising in the U.S. economy, as documented by Autor et al. $(2017 \mathrm{a}, \mathrm{b}) .^{3}$ Figure 1 demonstrates this trend in terms of the fraction of sales captured by the largest 4 and 20 firms, respectively, in each industry, while concentration measured by the Herfindahl-Hirschman index exhibits similar results. ${ }^{4}$ Grullon et al. (2017), analyzing Compustat data, arrive at a similar conclusion documenting the marked increase in market concentration in most U.S. industries in the post-2000 era. Akcigit and Ates (2019) show a similar pattern in patenting activity. Several other studies focus on rising market concentration and its aggregate implications [see Barkai (2017), Gutiérrez and Philippon (2016, 2017), Eggertsson et al. (2018)

\footnotetext{
${ }^{3}$ See Council of Economic Advisors (2016) and OECD (2018a) for a thorough discussion. By contrast, notes by some participating delegations [see OECD (2018c) by the U.S. delegation and OECD (2018b) by Business at OECD $(\mathrm{BIAC})]$ on the same subject doubt the notion of increased market concentration on the grounds of mismeasurement concerns and the lack of focus on relevant markets.

${ }^{4} \mathrm{An}$ article by the The Economist (2016) also emphasizes a rise in U.S. market concentration, providing evidence on the across-the-board increase from 1997 to 2012 in the share of sectoral revenues accruing to the top four firms in the United States.
} 
among others]..$^{5,6}$

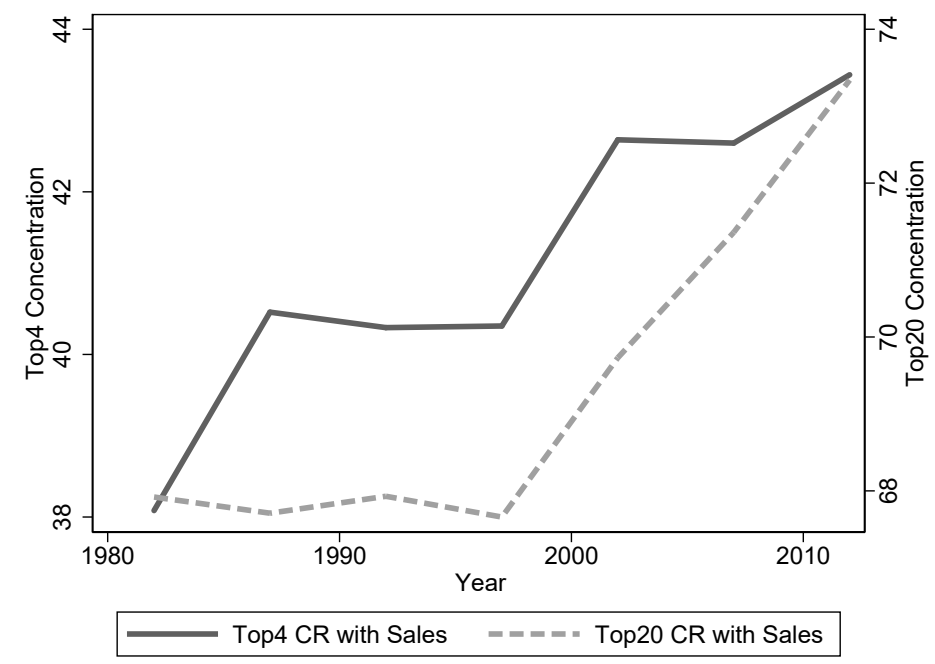

Source: Autor et al. (2017b). "Top4 CR with Sales" refers to the fraction of total sales accrued by four largest firms. "Top20 CR" is defined similarly.

Figure 1: MARKET CONCENTRATION.

\section{Fact 2. Markups Have Increased.}

The level of markups has been on the rise in the United States, as illustrated in Figure 2 [see Nekarda and Ramey (2013), De Loecker and Eeckhout (2017), Gutiérrez and Philippon (2017), Eggertsson et al. (2018), Hall (2018), among others; see De Loecker and Eeckhout (2018) for an international comparison]. Using cross-country data, Calligaris et al. (2018) also find a global rise in markups (driven by firms in the top decile of the markup distribution) and a widening average markup gap between digitally-intensive and other sectors. This trend has received notable attention because markups serve as a proxy for market power and concentration. Eggertsson et al. (2018) argue that a rise in the market power and markups of firms along with a lower natural rate of interest are responsible for several macroeconomic and asset-pricing trends in the United States observed since the 1970s. Similarly, Farhi and Gourio (2018) also find a notable contribution from rising market power to several macro-finance trends. ${ }^{7}$ Barkai (2017) also focuses on

\footnotetext{
${ }^{5}$ In his Wall Street Journal column, Larry Summers suggests that a rise in market power may be driving the symptoms of what he dubs "secular stagnation" (https://wapo.st/1UUF0sm?tid=ss_tw\&utm_term=.4df9b0193380). In a recent speech, Stiglitz (2017) emphasizes the role of regulation in the rise of firms' market power across the U.S. economy and discusses the adverse economic and political consequences of this shift, especially in terms of higher inequality.

${ }^{6}$ In a similar vein, Azar et al. (2017) document concentration in the U.S. labor market using disaggregated data at the geographical-occupational level.

${ }^{7}$ Of note, the authors emphasize that accounting for unmeasured use of intangible capital reduces the estimated effect of market power.
} 
the effect of declining competition and establishes a similar link between higher markups and lower capital and labor shares. It is, however, worth noting that recently there has been criticism regarding the evidence of rising markup trends on the grounds of measurement concerns-more precisely, the lack of "selling, general and administrative expenses" from variable input costs when computing markups [Karabarbounis and Neiman (2018), Traina (2018)].

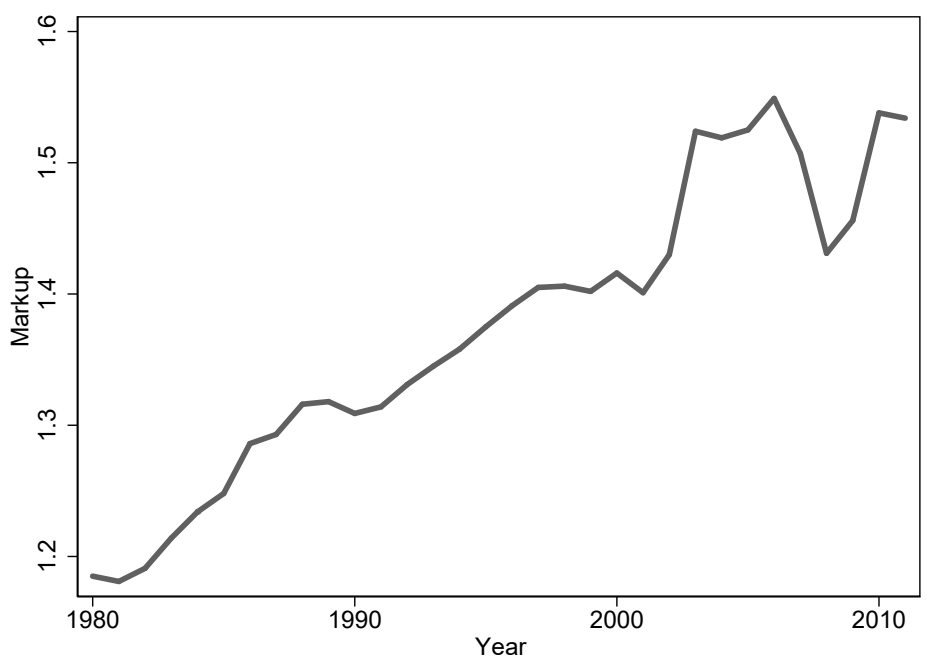

Source: De Loecker and Eeckhout (2017).

Figure 2: AvERAGE MARKUP OVER TIME.

\section{Fact 3. Profit Share of GDP Has Increased.}

Similar to markups, the profit share of GDP has been on the rise, as shown in Figure 3. Some recent papers investigate the implications of this trend. Gutiérrez and Philippon (2016) argue that higher within-industry concentration measured in terms of profitability is associated with weak investment. This result resonates with the findings of Eggertsson et al. (2018), who explore mechanisms that can give rise to higher profitability and lower investment-to-output ratio, along with several other changes. ${ }^{8}$ In a different approach, Aghion et al. (2018) explore the link between innovation and top income inequality in the United States and show evidence of the tight association between innovative activity per capita and profit share of output.

\section{Fact 4. The Labor Share Has Declined.}

Figure 4 demonstrates the steady decline in the labor share of output in the United States since the early 1980s [Karabarbounis and Neiman (2013), Elsby et al. (2013), Lawrence (2015)]. Kehrig and Vincent (2018) highlight an even stronger drop in the labor share in U.S. manufacturing

\footnotetext{
${ }^{8}$ The Economist (2018a) also documents rising average profitability of non-financial corporations in both the United States and Europe.
} 


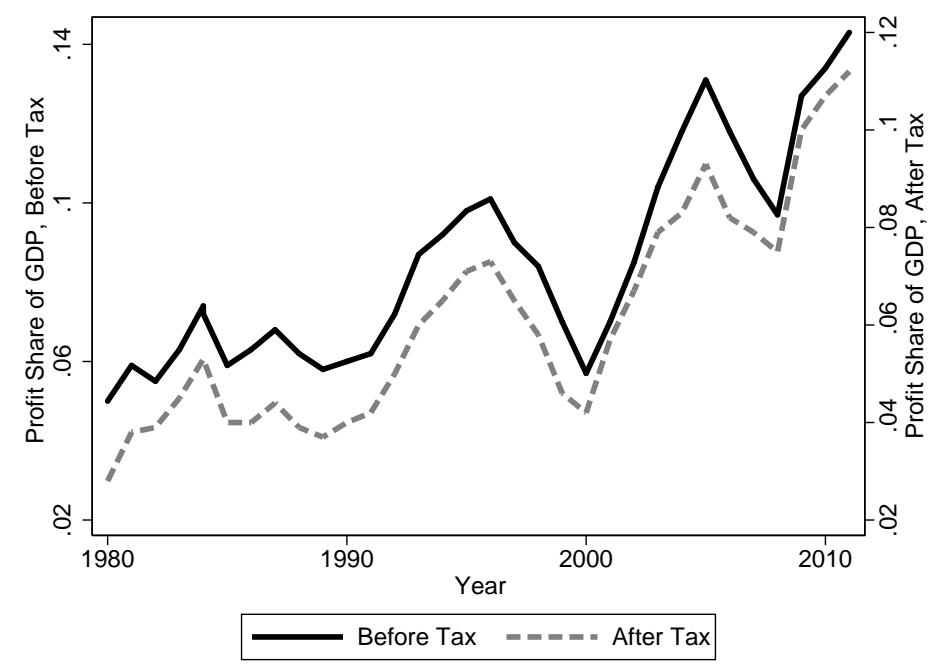

Source: Authors' own calculation using the BEA NIPA Table 1.15. The figure shows corporate profits of nonfinancial domestic U.S. firms adjusted for inventory valuation and capital consumption.

Figure 3: Profits as a FRACtion of GDP OVER TIME.

sector between the late 1960s and early 2010s. This trend has also an international nature, as highlighted by Karabarbounis and Neiman (2013) and Autor et al. (2017b).

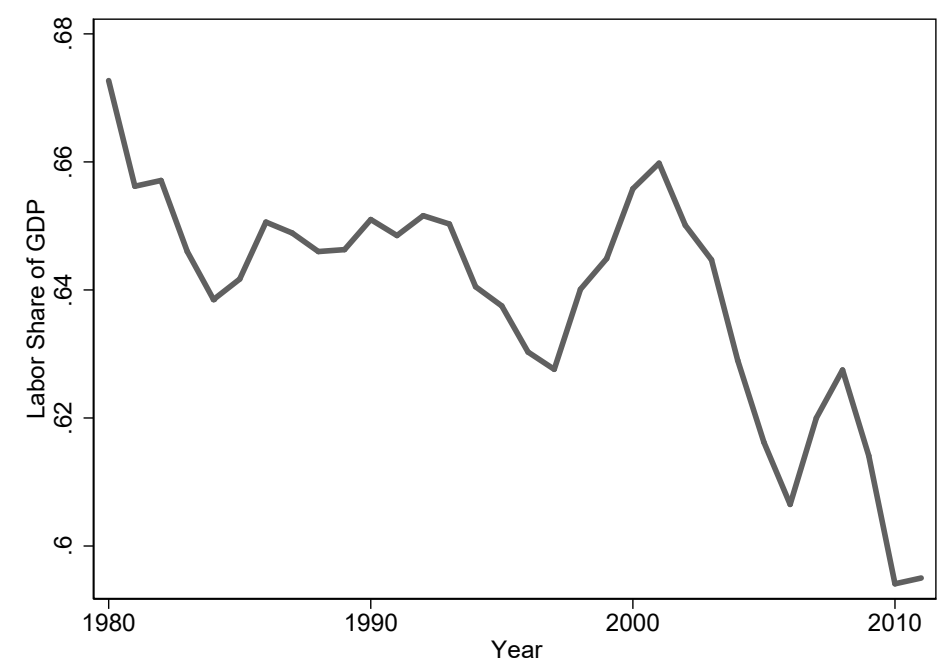

Source: Karabarbounis and Neiman (2013)

Figure 4: LABOR SHARE.

Fact 5. Market Concentration and Labor Share Are Negatively Associated.

Autor et al. (2017b), Barkai (2017), and Eggertsson et al. (2018) all point to a tight relation between the fall in the labor share and a rise in market concentration. Indeed, Figure 5, reproducing the findings of Autor et al. (2017b), demonstrates the negative correlation between the two variables 
across U.S. industries. Moreover, Autor et al. (2017b) contend that to the extent that changes such as globalization or new technological advances favor more productive companies, there arises a positive relationship between the level of firm productivity and its labor use (measured by payroll-to-sales ratio). The authors also provide suggestive evidence in this regard, namely, a positive association between industry-level productivity (measured by output per worker, patents per worker, etc.) and concentration (measured by fraction of sales accrued by 20 largest firms).

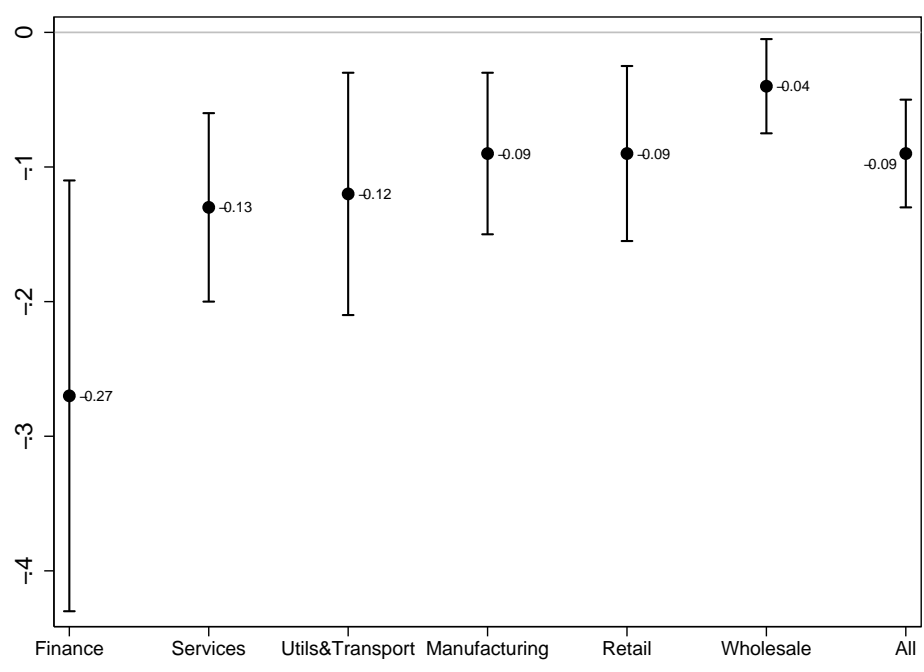

Source: Autor et al. (2017b)

Figure 5: CORRELATION BETWEEN SECTOR-LEVEL CHANGES IN CONCENTRATION AND LABOR SHARE.

\section{Fact 6. Labor Productivity Gap Between the Frontier and Laggard Firms Has Widened.}

One fact that is particularly informative about the underlying mechanism behind declining business dynamism concerns the labor productivity gap between frontier and laggard firms. Indeed, as shown in Figure 6, this gap has been on the rise [Andrews et al. $(2015,2016)]$. This figure replicates the findings of Andrews et al. (2016), which are based on a cross-country comparison of the top five percent of firms with the highest productivity level (frontier) to the rest of firms (laggard). ${ }^{9}$ The authors assert that this trend is worrisome in light of their finding that the aggregate productivity performance is weaker in industries where the divergence between frontier and laggard firms is stronger. Of note, Bettendorf et al. (2018) argue that a productivity divergence between frontier and laggard firms is non-existent in case of the Netherlands. 


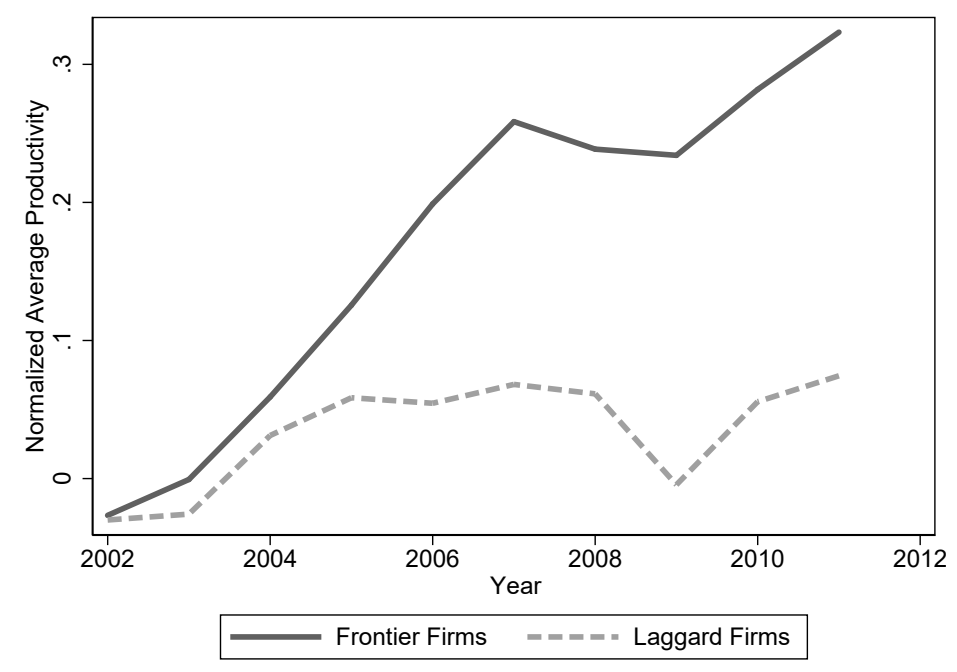

Source: Andrews et al. (2016)

Figure 6: LABOR PRODUCTIVITY OF FRONTIER AND LAGGARD FIRMS.

\section{Fact 7. Firm Entry Rate Has Declined.}

A widely debated symptom of declining business dynamism in the United States is the fall in firm entry [see Decker et al. (2016), Karahan et al. (2016), Gourio et al. (2014), among others]. Figure 7 illustrates this phenomenon using Business Dynamics Statistics data. This pattern is

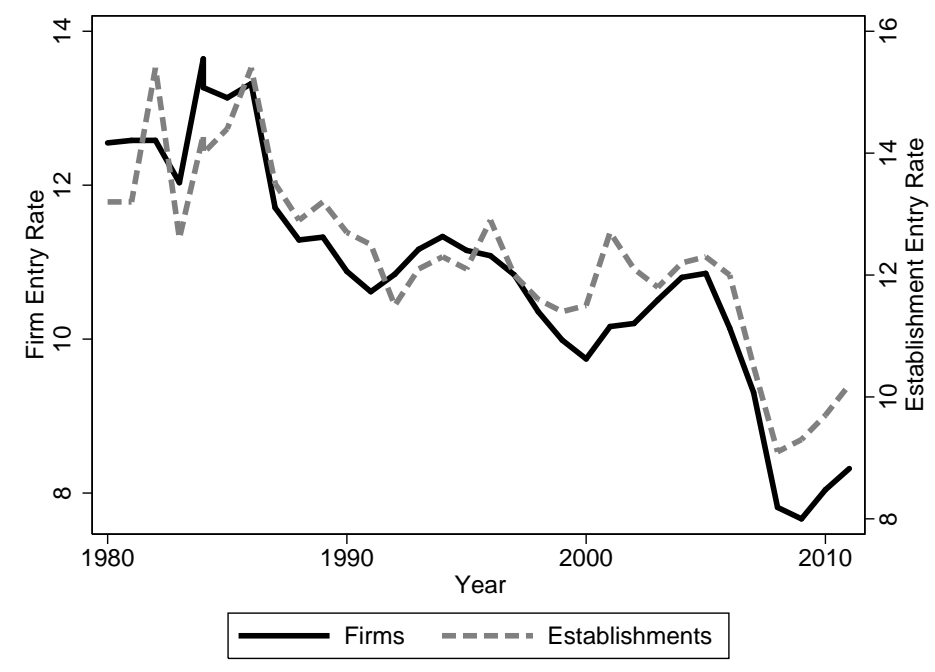

Source: Authors' calculations from BDS database [see also Decker et al. (2016)].

Figure 7: Firm entry and exit RATES IN THE United States.

\footnotetext{
${ }^{9}$ Although the study uses the Orbis database, whose coverage of U.S. firms is rather limited, the authors argue in a complementary work that the firms from advanced economies are well represented in the frontier group [Andrews et al. (2015)].
} 
also common to individual industries. A back-of-the-envelope calculation by Gourio et al. (2014) suggests that lower firm entry between 2006 and 2011 cost more than 1.5 million jobs. In their follow-up study, Gourio et al. (2016) use U.S. state-level data to find significant output losses driven by the forgone "missing generations."

\section{Fact 8. Economic Share of Young Firms Has Declined.}

The share of young firms in economic activity has been on a secular decline since the early 1980s, as highlighted by Decker et al. (2016) and Furman and Orszag (2018) (see Figure 8). ${ }^{10}$ Interestingly, other studies have shown that similar trends are present in several other advanced economies as well [e.g. Criscuolo et al. (2014), Binjens and Konings (2018)]. This decline is particularly concerning given the outsized contribution of surviving young firms to job creation of rapid growth [see Haltiwanger et al. (2013) in the context of the United States and Bravo-Biosca et al. (2013) for an international comparison]. Similarly, contrasting the life-cycle dynamics of businesses in India and the United States, Akcigit et al. (2015) show that managerial impediments to the selection and growth of highly productive young firms have considerable aggregate consequences in terms of productivity and income.

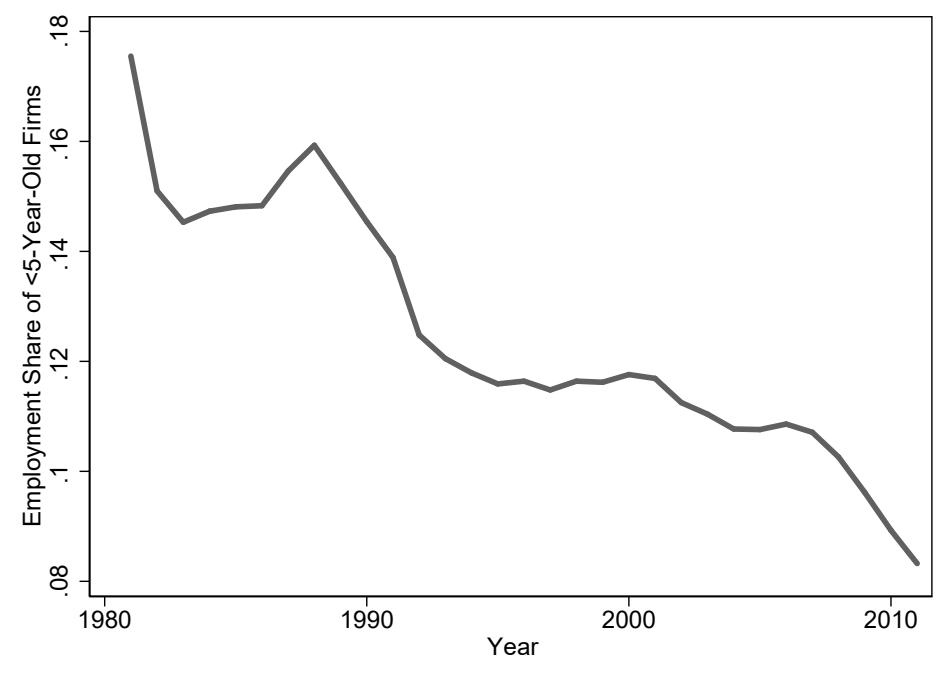

Source: Decker et al. (2016)

Figure 8: EMPLOYMENT SHARE OF <5-YEAR OLD FIRMS.

\section{Fact 9. Job Reallocation and Churn Have Gone Down.}

Figure 9 shows the secular decline in the gross job reallocation rate (defined as the sum of job creation and destruction rates) in the United States. Decker et al. (2016) provide a thorough

\footnotetext{
${ }^{10}$ Goldschlag and Miranda (2016) document that the decline has been especially pronounced in high tech-intensive sectors in the post-2000 period.
} 
analysis of this trend using confidential data from the Census Bureau. The decline has been apparent in the retail trade and services sectors for several decades, whereas in the information sector a pronounced decline started in the early 2000s. Davis and Haltiwanger (2014) show that a fall in labor market fluidity was common to several other countries during the 2000s, though to a weaker extent than in the United States in most of them. This phenomenon is possibly a concern for the health of the economy because it implies less job opportunities, longer unemployment spells, lower wage growth [Hagedorn and Manovskii (2013)], and worse job-worker matches [Akerlof et al. (1988)].

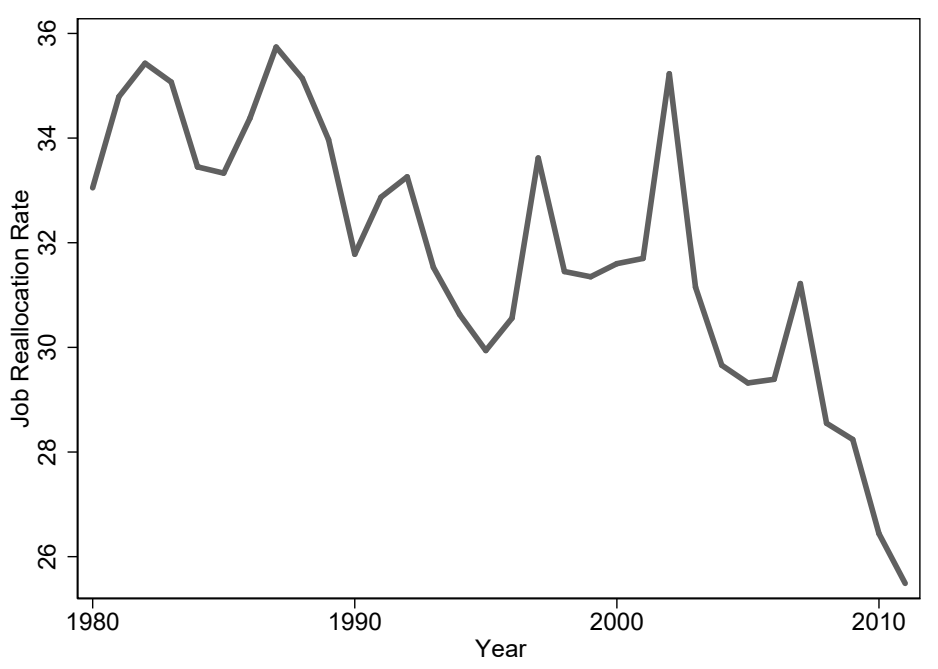

Source: Decker et al. (2016)

Figure 9: Gross JOB REALlocation.

\section{Fact 10. The Dispersion of Firm Growth Rates Has Gone Down.}

Along with a decline in the activity by young (and high-growth) firms, the dispersion of firm growth (measured by standard deviation or skewness) moved down as well, as demonstrated by Decker et al. (2016) (see Figure 10). Using data from the U.S. Census Bureau, Decker et al. (2016) also document industry-level heterogeneity in this margin. In particular, they argue that the decline in growth dispersion has become stronger in the post-2000 period, as young firm activity in high-tech sectors, which were the sectors that exhibited high growth dispersion to begin with, started to lose steam.

\section{Potential Causes of Declining Business Dynamism}

As discussed in the previous section, a large and growing body of work presents evidence of a slowdown in U.S. business dynamism and its manifestations through several potentially re- 


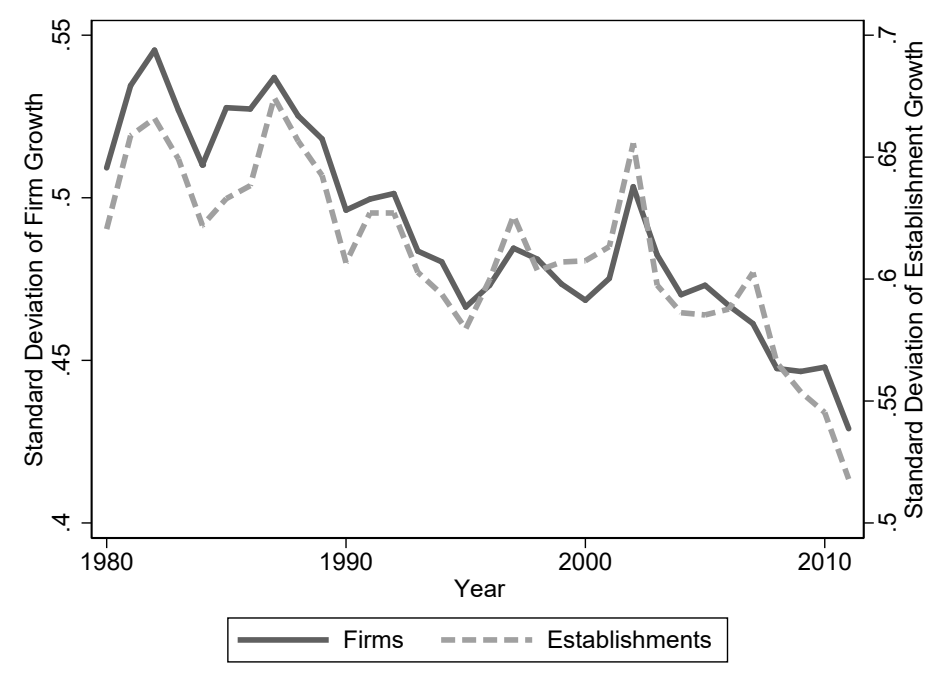

Source: Decker et al. (2016)

Figure 10: GROWTH RATE DISPERSION HAS SHRUNK.

lated dimensions. The question that naturally follows is, of course, What is the driving force behind these developments? The answer to this question is still being debated. The literature has proposed various candidates, albeit often focusing on specific aspects of business dynamics, including demographic shifts, sectoral changes, regulations, among others. In this section, we summarize these likely candidates.

As the culprit for the declining pace of startup creation, some researchers have focused on structural changes to the economy. Karahan et al. (2016) argue that "demographic" shifts were the main driver of declining U.S. entrepreneurship. In particular, they argue that the slowdown in the growth rate of the U.S. labor force with the end of the "baby-boomer" generation led to a rise in wages and, in turn, a decline in the firm entry rate. ${ }^{11}$ Another structural-shift-based explanation for the fall in the firm entry rate relies on the Gordon (2016) argument that the economy has run out of low-hanging fruit innovations-i.e., ideas that are relatively easier to obtain and have farreaching spin-off applications. Bloom et al. (2017) support this view, arguing that research efforts have been increasing, while their productivity has been falling, likely exacerbated by dead-end duplication of effort as described in Akcigit and Liu (2016). A decline in patent to R\&D ratio was also observed by Kortum (1997). Through the lens of Gort and Klepper (1982), a lower arrival rate of impactful innovations would translate into lower rates of firm entry.

Focusing on job flows, Decker et al. (2018) argue that the culprit behind declining dynamism is the declining responsiveness of firms to shocks rather than a structural change in the nature of those idiosyncratic shocks. They argue that the declining responsiveness likely reflects difficulties

\footnotetext{
${ }^{11}$ Similarly, Aksoy et al. (2018) analyze the effects of demographic trends in 21 OECD countries over the period between 1970 and 2014 using a panel VAR framework. The authors find that population aging reduce aggregate output growth and investment by dampening innovative activity.
} 
in the employment adjustment margin, which may depend on a variety of factors [see Decker et al. (2016) for a succinct overview]. For instance, Davis and Haltiwanger (2014) suggest that lower worker fluidity may be a reflection of widespread occupational licensing practices or the inhibitory effects of employment protection regulations. ${ }^{12}$

Analyzing the decreasing labor share in the economy, some recent studies focus on the role of "superstar" firms-very productive firms that dominate the industries in which they operateand the concentration of economic activity in the hands of these firms. Autor et al. (2017b) show that the product market concentration across U.S. industries has been increasing in the last several decades and that the industries with the highest concentration of sales are the ones with the largest declines in the labor share. The authors also provide evidence that the concentration dynamics due to superstar firms are more pronounced in "winner-takes-all" industries. ${ }^{13}$ These findings are consistent with the analysis of Kehrig and Vincent (2018) who, using data from U.S. Census of Manufactures, document the shift of value added to hyper-productive low laborshare establishments. Using cross-country data, Diez et al. (2018) also find empirical support for the increasingly dominant role of superstar firms. The authors argue that the market power of superstar firms, manifesting itself in higher markups and profit margins, has been on the rise and is negatively associated with the labor share of output. Similarly, Barkai (2017) also finds a link between higher concentration and lower labor (and capital) share. ${ }^{14,15}$

One potential driver of rising market concentration may be the nature of new technologies and the increasing importance of the use of (often big and proprietary) data and tacit knowledge in production processes along with the rise of ICT-intensive sectors. ${ }^{16}$ Digitalization, reliance

\footnotetext{
${ }^{12}$ Furman and Giuliano (2016) documents that about a quarter of U.S. workers hold occupational licenses, a dramatic increase since the 1950s. As to the effect of non-compete laws, see Marx et al. (2009). Using a seemingly exogenous variation in non-compete laws in Michigan, the authors show the attenuating effect of such policies on labor mobility. White House (2016) highlights that non-compete contracts bind a sizable fraction of workers even those without a four-year college degree and those earning less than $\$ 40,000$, suggesting an abuse of the laws, possible in ways harmful to job reallocation. See Wessel (2018) for a brief non-technical account of regulatory concerns in light of competition.

${ }^{13}$ Andrews et al. (2016) show the prominence of ICT-intensive sectors, which are more likely to be of a "winnertakes-all" nature, in the differential productivity dynamics of frontier and non-frontier firms. In his Jackson Hole remarks, Van Reenen (2018) contends that a growing part of the U.S. economy has gained winner-takes-most/all characteristics, possibly thanks to globalization and/or technological advances.

${ }^{14}$ As one of the manifestations of increasing market power of superstar firms, the literature has cited increasingly higher return on invested capital (ROIC) by superstar firms relative to others. A recent paper by Ayyagari et al. (2018) challenges this point. The authors argue that the increasingly unequal distribution of ROIC is driven by the mismeasurement of intangible capital. Still, the authors acknowledge that there may be other channels through which superstar firms exercise higher market dominance in ways that are harmful for the economic activity in the longer term. Preemptive mergers, in which large firms buy out smaller prospective competitors, is one such strategy [see Cunningham et al. (2018), The Economist (2018b)]. Similarly, Blonigen and Pierce (2016) find that mergers and acquisitions in the U.S. manufacturing industry result in higher markups without generating any significant productivity gains.

${ }^{15}$ Other explanations for declining labor share proposed in the literature include offshoring [Elsby et al. (2013), and Boehm et al. (2017) in the context of U.S. manufacturing industry], declining corporate tax rates [Kaymak and Schott (2018)], substitution of production workers by automated machinery [Acemoglu and Restrepo (2017)], and a decline in population growth [Hopenhayn et al. (2018)].

${ }^{16}$ In their Jackson Hole remarks, Crouzet and Eberly (2018) document the positive association between the intensity
} 
on data, and the use of tacit knowledge can favor large and more productive firms in ways that hamper the diffusion of technology from frontier to laggard firms, as stressed by Andrews et al. (2016). ${ }^{17}$ Calligaris et al. (2018) find that markups are higher in digitally intensive sectors relative to non-digitally intensive ones. Bessen (2017) finds that industry concentration measured by sales ratios is strongly associated with the industry-level intensity of ICT use. Autor et al. (2017b) find evidence that suggests a negative association between industry concentration and slower technology diffusion measured by the speed of patent citations. These findings may reflect that firms that better adapt to new technologies can gain a relatively more advantageous position compared to their competitors and can capture outsized market power. For instance, Grullon et al. (2017) find that in the post-2000 period, U.S. firms in more concentrated markets possess a larger number of patents as well as more valuable ones, which the authors interpret to be indicative of higher entry barriers in such sectors.

Regulations may be another driver of lower technology diffusion between firms, causing higher market concentration. Andrews et al. (2016) argue that lack of pro-competitive and extensive product market reforms exacerbated the widening productivity gap between frontier and laggard firms in retail services sectors across OECD economies in the post-2000 period. Grullon et al. (2017) find support for weaker antitrust law enforcement in the United States. This finding resonates with several legal studies that underscore a paradigm shift in the application of antitrust regulations toward the Chicago school, which emphasizes product market efficiency in the interpretation of laws [see Baker (2012), Khan (2016), Lynn (2010)]. Using U.S. data on lobbying and campaign spending activity, Bessen (2016) argues that political rent seeking played a disproportionate role in rising corporate profit margins in the United States in the post-2000 period. Using a cross-country approach, Haltiwanger et al. (2014) also stress the role of strict hiring and firing regulations in the reduced pace of job reallocation. ${ }^{18}$

Finally, a heated debate on which our discussion of declining business dynamism could potentially shed some light concerns trends in U.S. aggregate productivity growth (labor or multi-factor) in the last several decades. Except for a short period of increase between roughly the mid-1990s and mid-2000s, U.S. productivity growth appears to be falling steadily [Gordon (2012)]. ${ }^{19}$ As discussed earlier, Gordon (2016) concludes that broad-impact innovations have been depleted, which implies a structurally low aggregate growth in the foreseeable future, a predic-

of intangible-capital use and concentration at both the industry and firm level. See also Furman and Seamans (2018) for the growing role that artificial intelligence (AI) plays in economic activity. The authors also discuss the case for a tailored regulatory framework in the face of economic implications specific to AI and the productive use of data more broadly.

17 An article by the The Economist (2017b) also highlights the concern that large proprietary data bring an outsized market advantage to firms that possess them.

${ }^{18}$ Goldschlag and Tabarrok (2018) find no relationship between increasing federal regulations and declining U.S. entrepreneurship and challenge the notion that regulations might be behind secular trends in U.S. business dynamism.

${ }^{19}$ Syverson (2017) and Ahmad et al. (2017) refute the argument that the measured slowdown in aggregate productivity growth may reflect measurement problems. The studies conclude that even if there was mismeasurement, it could only account for a small part of the decline. 
tion shared by Fernald (2014). Brynjolfsson and McAfee (2014) and Brynjolfsson et al. (2017) disagree, arguing that the diffusion of new technologies such as artificial intelligence will boost productivity growth going forward, whereas Nordhaus (2015) expects the opposite. ${ }^{20}$ While understanding the long-term future of aggregate productivity is very intriguing in itself and has far-reaching implications, this topic is beyond the scope of this paper. Before trying to delve into this debate, we first aim to understand declining U.S. business dynamism in an all-encompassing manner, which is itself a daunting task. Therefore, we leave this topic aside for now, with the hope that we can contribute to it in future work.

\section{Model with Endogenous Markups and Innovation}

In this section, we present a theoretical model of innovation and firm dynamics. ${ }^{21}$ The framework draws on step-by-step innovation models of endogenous growth [Aghion et al. (2001, 2005), Acemoglu and Akcigit (2012), Akcigit et al. (2018)] and is a simplified version of the model studied by Akcigit and Ates (2019). In our analysis, we will discuss the analytical implications of the model in light of the empirical regularities listed in Section 2, focusing on the balanced growth path (BGP) equilibrium. For a quantitative analysis that also accounts for the transition path, we refer the interested reader to Akcigit and Ates (2019). A number of crucial features of the model are worth emphasizing: (i) Firms have strategic investment decisions-a key to understanding declining business dynamism, (ii) productivity enhancing innovation decisions are endogenous, (iii) thus, markups are endogenous, depending on the technology gap between competitors, and (iv) a reduced-form parameter governs the process of knowledge diffusion, keeping technology gaps within some limits.

In our model, a representative final good firm combines a continuum of intermediate goods to produce the final output. There is a unit measure of intermediate good product lines, and in each of them, two intermediate good firms compete to enjoy the monopoly power of production. Intermediate firms produce the same product but with different productivities. The firm with a higher productivity - the leader - is able to capture the market and reaps the monopoly rents. Firms invest in research and development activities to improve their productivity and take over the market ownership. Importantly, we assume that there is an exogenous flow of knowledge from the market leader to the follower that allows the follower to close the productivity gap with the leader, bringing them to a neck-and-neck position. The Poisson rate of this knowledge diffusion will be crucial in our analysis; in particular, we will show that a weakening in this margin can generate some of the observed changes in the economy.

\footnotetext{
${ }^{20}$ Fernald and Jones (2014) also point to a possible pickup in aggregate productivity growth due to the productivity-improving contribution of AI. They also mention potential spillovers from R\&D conducted in developing countries such as South Korea and China, which are poised to provide vast resources for innovative activity.

21 Azar and Vives (2018) analyze some of the observed trends in U.S. business dynamism in a general equilibrium model of oligopoly that explicitly accounts for common ownership of firms.
} 


\subsection{Basic Environment}

Preferences We consider the following closed economy in continuous time. A unit measure of representative households consume the final good with log-utility preferences

$$
U_{t}=\int_{t}^{\infty} \exp (-\rho(s-t)) \ln C_{s} d s,
$$

where $C_{t}$ represents consumption at time $t$, and $\rho>0$ is the discount rate. The budget constraint of the representative consumer reads as

$$
C_{t}+\dot{A}_{t}=w_{t} L_{t}+r_{t} A_{t}
$$

where $A_{t}$ denotes total assets and $L_{t}$ denotes labor (supplied inelastically). We normalize the total labor supply to one, such that $L_{t}=1$. The relevant prices are the interest rate $r_{t}$, and the wage rate $w_{t}$. We normalize the price of the consumption good to one without loss of any generality. Households own the firms in the economy, and the asset market clearing condition implies that the total assets $A_{t}$ equal the sum of firm values, $A_{t}=\int_{\mathcal{F}} V_{f t} d f$, where $\mathcal{F}$ is the set of firms in the economy.

Final Good The final good $Y_{t}$ is produced in a perfectly competitive market according to the following production technology:

$$
\ln Y_{t}=\int_{0}^{1} \ln y_{j t} d j
$$

where $y_{j t}$ denotes the amount of intermediate variety $j \in[0,1]$ used at time $t$. The final good is used for consumption and R\&D investment. Hence the resource constraint of the economy is simply

$$
Y_{t}=C_{t}+R_{t}
$$

with $R_{t}$ denoting the aggregate $R \& D$ expenditure. Next, we describe the production of intermediate varieties.

Intermediate Goods and Innovation In each product line $j$, there are two incumbent firms $i \in\{1,2\}$ that can produce a perfectly substitutable variety of good $j$. Total output of variety $j$ is given by

$$
y_{j}=y_{i j t}+y_{-i j t}
$$

where $-i$ denotes the competitor of firm $i$, such that $-i \in\{1,2\}$ and $-i \neq i$. Each firm produces according to the following linear production technology:

$$
y_{i j t}=q_{i j t} l_{i j t}
$$


Here, $l_{i j t}$ denotes the labor employed, and $q_{i j t}$ is the associated labor productivity of firm $i$. These firms compete for market leadership à la Bertrand. The firm that has a higher labor productivity enjoys a cost advantage, which enables it to supply the entire market of good $j$. We call firm $i$ the market leader and $-i$ the follower in $j$ if $q_{i}>q_{-i}$. The two firms are neck-and-neck if $q_{i}=q_{-i}$.

Firms can improve their productivity by investing in innovation activity. If an innovation arrives in time $(t, t+\Delta t)$, it increases the innovating firm's productivity level proportionally by a factor $\lambda>1$ such that

$$
q_{i j(t+\Delta t)}=\lambda q_{i j t}
$$

Assuming an initial value of $q_{i j 0}=1$, we can summarize the quality levels at time $t$ by $q_{i j t}=\lambda^{n_{i j t}}$, where $n_{i j t}$ captures the number of quality improvements that took place by firm $i$ since time 0 . The productivity difference between a leader and its follower reflects the difference between the total number of technology rungs these firms' productivities build on. In this simplified setting, we assume that this difference can be at most one step such that the economy consists of two types of product lines: leveled and unleveled. Then, the relative productivity level is given by

$$
\frac{q_{i j t}}{q_{-i j t}}=\frac{\lambda^{n_{i j t}}}{\lambda^{n_{-i j t}}}=\lambda^{n_{i j t}-n_{-i j t}} \equiv \lambda^{m_{i j t}},
$$

where $m_{i j t} \in\{-1,0,1\}$ defines the technology gap between the firm $i$ and $-i$ in sector $j$. The technology gap between the two firms is a sufficient statistic to describe firm-specific payoffs, and, therefore, we will drop industry subscript $j$ and use the notation $m_{i t} \in\{-1,0,1\}$ whenever $m$ is specified to denote a firm-specific value. Likewise, we will use $m_{j t} \in\{0,1\}$ to index sectors that are leveled or unleveled.

Firms invest in R\&D to eventually take over the production by improving their productivity. When a firm invests $R_{i j t}$ units of final good, it generates an innovation with the arrival rate of $x_{i j t}$. Following a large empirical literature that estimates the innovation cost function ${ }^{22}$, we consider a quadratic cost of generating the arrival rate $x_{i j t}$, denoted by $R_{i j t}$, such that

$$
R_{i j t}=\alpha \frac{x_{i j t}^{2}}{2} Y_{t}
$$

In this expression, $\alpha$ determines the scale of the cost function and $Y_{t}$ ensures that the cost scales with the size of the economy.

In addition, we assume that knowledge may diffuse from the leader to the follower at an exogenous Poisson flow rate $\delta$. Knowledge diffusion enables the follower to catch up with the leader's productivity level, bringing both firms to a neck-and-neck position. We interpret this

\footnotetext{
${ }^{22}$ Among many others, see Griliches (1990), Blundell et al. (2002), Hall and Ziedonis (2001), and Akcigit and Kerr (2018). Another set of papers [e.g., Hall (1992), Bloom et al. (2002), Wilson (2009), and Hall and Van Reenen (2000)] estimates the tax price elasticity of R\&D spending and finds a value of unity, which corresponds to a quadratic cost function in our case.
} 
exogenous catch-up probability to reflect the degree of knowledge diffusion or intellectual property rights (IPR) protection as in Acemoglu and Akcigit (2012), with lower values of $\delta$ implying higher protection and lower catch-up. A leaders' patent expires with the flow rate $\delta$, allowing the follower to replicate the frontier technology and catch-up with the leader.

In Figure 11, we demonstrate how leadership positions in intermediate product lines evolve as a result of innovations. The left panel exhibits five product lines with different degrees of competition, with the first three lines being unleveled and the last two being leveled. Red circles denote leaders, blue squares denote followers, and black diamonds denote neck-and-neck firms. If firm $i$ leads in an unleveled line, then $q_{i}=\lambda q_{-i}$, resulting in heterogeneous differences between quality levels. The right panel shows the changes in leadership. In line 1, the follower catches up with the previous leader with help of an exogenous shock of knowledge diffusion, while in line 2, the follower catches up with an endogenous innovation. In line 4, a neck-and-neck firm innovates and escapes intense competition, capturing the market leadership. In line 3 and 5, there is no change as no firm innovates (and as the follower in line 3 does not receive an exogenous shock).

productivity, $q$

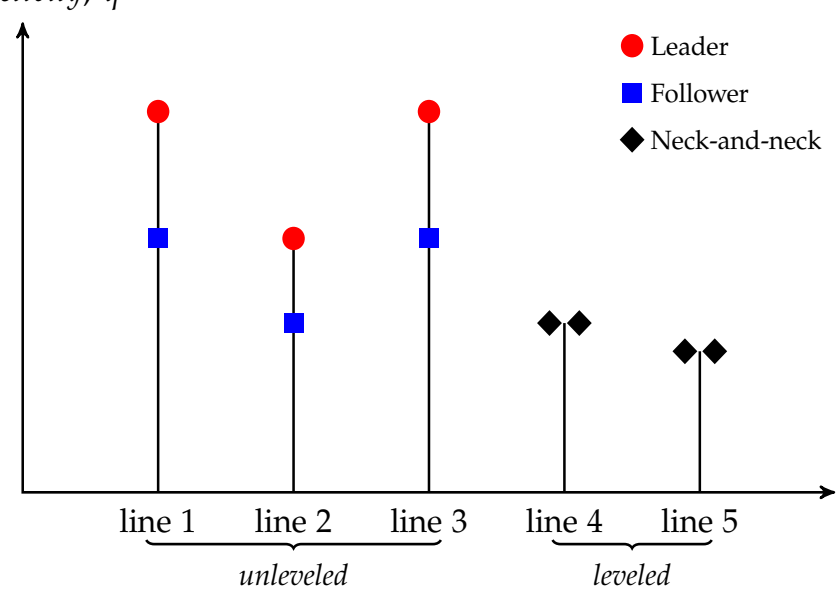

A) Product lines

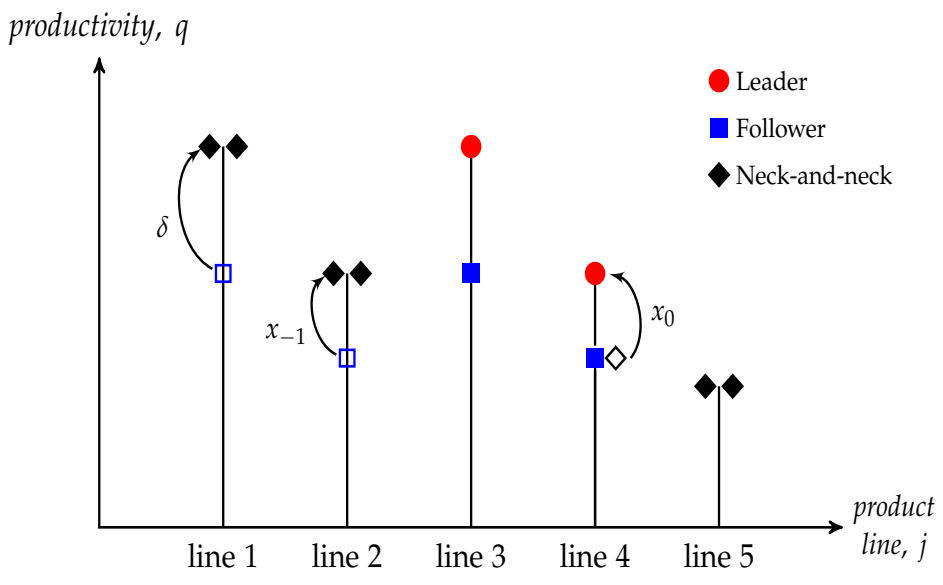

в) Entry, exit, and leadership

Figure 11: Evolution of product lines

Notes: Panel A exhibits the positions of competing incumbent firms in leveled and unleveled industries with heterogeneous productivity levels. If firm $i$ leads in an unleveled line, then $q_{i}=\lambda q_{-i}$, resulting in heterogeneous differences between quality levels. Panel B illustrates the effects incumbent innovation on industry leadership. Empty squares or circles denote the previous position of innovating firms. 


\subsection{Equilibrium}

Next, we focus on the Balanced Growth Path (BGP) Markov perfect equilibrium, with equilibrium strategies depending only on the payoff-relevant state variable $m \in\{-1,0,1\}$ and all aggregate variables growing at the same rate $g$. Henceforth, we will drop the indices $i, j$ and $t$ when it causes no confusion and use only the pay-off relevant state variable $m$. We first focus on the static equilibrium and then present the details of firm value functions, innovation decisions, and the resulting aggregate dynamics.

Households Optimal household decisions determine the equilibrium interest through the Euler equation such that

$$
r=g+\rho,
$$

where $g$ is the BGP growth rate of consumption.

Final and Intermediate Good Production The optimization of the representative final good producer generates the following demand schedule for the intermediate good $j \in[0,1]$ :

$$
y_{i j}=\frac{Y}{p_{i j}}
$$

where $p_{i j}$ is the price of intermediate $j$ charged by the producing monopolist $i$. Notice that the unit-elastic demand implies that the final good producer spends an equal amount $Y$ on each intermediate $j$.

The linear production function for intermediate goods implies that an intermediate producer's marginal cost is

$$
M C_{i j}=\frac{w}{q_{i j}}
$$

with $w$ denoting the wage level. The marginal cost of production increases in the labor cost $w$ and decreases in labor productivity $q_{i j}$. Bertrand competition leads to limit pricing such that the intermediate producer sets its price to the marginal cost of its competitor:

$$
p_{i j}=\frac{w}{q-i j} .
$$

We define the normalized wage rate in the economy, which also corresponds to the labor share, as

$$
\omega \equiv \frac{w}{Y} .
$$


Then the equilibrium intermediate good quantities are simply

$$
y_{i j}=\frac{q_{-i j}}{\omega} \text { for } q_{i j} \geq q_{-i j}
$$

and $y_{i j}=0$ otherwise. We assume that production is randomly assigned to both firms in that period when $q_{i j}=q_{-i j}$. The optimal production employment of the intermediate producer is given by

$$
l_{i}=\frac{y_{i}}{q_{i}}=\frac{1}{\omega \lambda^{m_{i}}} \text { for } m_{i} \in\{0,1\} .
$$

It follows that the operating profits of an intermediate firm exclusive of its R\&D expenditures becomes $\pi\left(m_{i}\right)=\left(p_{i}-M C_{i}\right) y_{i}$ which implies

$$
\pi\left(m_{i}\right)=\left\{\begin{array}{c}
\left(1-\frac{1}{\lambda}\right) Y \quad \text { if } \quad m_{i}=1 \\
0 \text { if } \quad m_{i} \in\{0,-1\}
\end{array}\right.
$$

Notice that the markup, and thus the profit level, is positive only for the leader. Therefore, the model provides a useful starting point to analyze the dynamics of markups in an economy, which are determined by the distribution of intermediate lines across leveled and unleveled ones. That, in turn, crucially depends on firms' endogenous innovation decisions. More specifically, combining (5) and (6), the markups in leveled $\left(m_{j}=0\right)$ and unleveled $\left(m_{j}=1\right)$ sectors are

$$
\operatorname{Markup}_{j}=\frac{p_{i j}}{M C_{i j}}-1=\left\{\begin{array}{c}
\lambda-1 \quad \text { if } \quad m_{j}=1 \\
0 \quad \text { if } \quad m_{j}=0
\end{array}\right.
$$

We are now ready to solve for the aggregate wage and output. To this end, we first define

$$
Q \equiv \exp \left(\int_{0}^{1} \ln q_{j} d j\right)
$$

as the aggregate productivity index of the economy. Moreover, we denote the share of unleveled industries, which also acts as a proxy for the level of market concentration, by

$$
\mu \equiv \int_{0}^{1} \mathbb{I}\left(q_{i j} \neq q_{-i j}\right) d j .
$$

Then the final good production function (1) and the equilibrium intermediate goods (7) yield

$$
w=\frac{Q}{\lambda^{\mu}}
$$


Moreover, the labor market clearing condition, $\int_{0}^{1} l_{j t} d j=1$, yields the labor share $\omega$ as

$$
\omega=1-\mu \frac{(\lambda-1)}{\lambda}
$$

This expression (10) shows the behavior of the labor share in the model. Note that the labor share is decreasing the level of market concentration $\mu$, and the markup parameter $\lambda$. If market concentration rises (i.e., $\mu$ increases), labor share falls in return.

Combining equations (9) and (10) gives the level of final output as

$$
Y=\frac{Q}{\lambda^{\mu}\left[1-\mu \frac{(\lambda-1)}{\lambda}\right]} .
$$

Notice that, along the BGP, final output is proportional to the aggregate productivity index. Therefore, the long-run growth rate of output and consumption are determined by the growth rate of aggregate productivity. Note another interesting result that emerges from (11): The distribution of markups creates some static efficiency losses. For instance, if the economy is least concentrated $(\mu=0)$, or most concentrated $(\mu=1)$, then we have $Y=Q$. However, when markups are unevenly distributed across the sectors, then the economy suffers from some additional efficiency losses.

Firm Values and Innovation We denote the stock market value of a firm that is in state $m_{i} \in$ $\{-1,0,1\}$ by $V_{m_{i}}$. Then, the value function of an incumbent firm that is one-step ahead, i.e., $m_{i}=1$, is given by

$$
r V_{1}-\dot{V}_{1}=\max _{x_{1}}\left\{\left(1-\frac{1}{\lambda}\right) Y-(1-s) \alpha \frac{x_{1}^{2}}{2} Y+x_{1}\left[V_{1}-V_{1}\right]+\left(x_{-1}+\delta\right)\left[V_{0}-V_{1}\right]\right\} .
$$

The first two terms on the right-hand side of the expression capture the profits net of R\&D expenditure. The third term captures the result of a successful innovation by the leader. ${ }^{23}$ The fourth term reflects the result of a follower innovation or the exogenous knowledge diffusion, which happens a rate $\delta$. In these cases, the leader loses its productivity advantage and becomes neck-and-neck with the competitor.

Reciprocally, the value of function of a follower is defined as

$$
r V_{-1}-\dot{V}_{-1}=\max _{x_{-1}}\left\{-\alpha \frac{x_{-1}^{2}}{2} Y+\left(x_{-1}+\delta\right)\left[V_{0}-V_{-1}\right]\right\}
$$

Notice that the follower does not produce and, therefore, does not earn any profits. Yet, the firm

\footnotetext{
${ }^{23}$ When the one-step leader innovates, the gap difference does not increase because of the imposition of an upper limit on the potential size of gaps. As a result, a one-step leader optimally chooses not to invest in R\&D.
} 
is forward looking and thus invests in R\&D with the prospect of first catching up with the leader and then taking it over through successive innovations. Notice that catch-up can also happen at the exogenous flow rate $\delta$. Finally, the value of a neck-and-neck incumbent is given by

$$
r V_{0}-\dot{V}_{0}=\max _{x_{0}}\left\{-\alpha \frac{x_{0}^{2}}{2} \Upsilon+x_{0}\left[V_{1}-V_{0}\right]+x_{0}\left[V_{-1}-V_{0}\right]\right\} .
$$

A successful innovation of the neck-and-neck firm makes it a leader, whereas an innovation by the competitor makes it a follower.

To solve for the equilibrium innovation efforts, which are all stationary in the BGP, we first normalize firm values in Lemma 1 and turn them into stationary objects.

Lemma 1 Define the normalized BGP value $v_{m}$ such that $v_{m_{i}} \equiv V_{m_{i}} / Y$. Then, for $m_{i} \in\{-1,0,1\}, v_{m_{i}}$ is given by

$$
\begin{aligned}
\rho v_{1} & =\max _{x_{1}}\left\{\left(1-\frac{1}{\lambda}\right)+x_{1}\left[v_{1}-v_{1}\right]+\left(x_{-1}+\delta\right)\left[v_{0}-v_{1}\right]\right\} \\
\rho v_{-1} & =\max _{x_{-1}}\left\{-\frac{x_{-1}^{2}}{2}+\left(x_{-1}+\delta\right)\left[v_{0}-v_{-1}\right]\right\} \\
\rho v_{0} & =\max _{x_{0}}\left\{-\frac{x_{0}^{2}}{2}+x_{0}\left[v_{1}-v_{0}\right]+x_{0}\left[v_{-1}-v_{0}\right]\right\} .
\end{aligned}
$$

Proof. It follows directly from substituting $v_{m_{i}} Y$ for $V_{m_{i}}$ and using Euler equation (3).

The first order conditions of the problems defined above yield the following optimal innovation decisions:

$$
\begin{aligned}
x_{1} & =0 \\
x_{0} & =v_{1}-v_{0} \\
x_{-1} & =v_{0}-v_{-1} .
\end{aligned}
$$

The aggregate BGP R\&D expenditure is

$$
R=\left(\mu \frac{x_{-1}^{2}}{2}+(1-\mu) \frac{x_{0}^{2}}{2}\right) \Upsilon
$$

The law of motion for $\mu$ is as follows:

$$
\dot{\mu}=-\mu\left(x_{-1}+\delta\right)+(1-\mu) 2 x_{0} .
$$

The unleveled sectors become leveled at the rate $x_{-1}+\delta$ and therefore the mass of sectors that leave the unleveled state is simply $\mu\left(x_{-1}+\delta\right)$. However, leveled sectors become unleveled as 
soon as one of the two neck-and-neck firms innovate, which happens at the rate $2 x_{0}$. Therefore, the mass of sectors that enter into the unleveled state is $(1-\mu) 2 x_{0}$.

In the BGP, the share of unleveled sectors remains constant, $\dot{\mu}=0$; therefore, the share of unleveled sectors is

$$
\mu=\frac{2 x_{0}}{2 x_{0}+x_{-1}+\delta}
$$

Finally, we show the equilibrium growth rate of this economy in the following Lemma.

Lemma 2 The BGP growth rate of the above economy is

$$
g=2 x_{0}(1-\mu) \ln \lambda
$$

Proof. See the appendix.

The growth rate of the economy is determined by innovations of neck-and-neck firms, which improve the productivity of workers employed in intermediate-good production. The surprising result here is that firms in unleveled sectors do not contribute to the BGP growth. This happens because while the leaders do not invest in innovation, the followers do not push the frontier forward but rather catch-up with the leader's technology level. Therefore market concentration $(\mu)$ has a negative impact on economic growth $(g)$.

Next, we define the equilibrium. When deriving our analytical results we will focus on the BGP equilibrium, where all aggregate variables grow at a constant rate while firms' innovation rates remain constant.

Definition 1 (Equilibrium) A BGP Markov perfect equilibrium in this economy is an allocation

$$
\left\{y_{i j}, p_{i j}, x_{i j}, R, Y, C, w, r, \mu, g\right\}_{j \in[0,1]}
$$

such that (i) the sequence of intermediate quantities and prices $\left\{y_{i j}, p_{i j}\right\}$ satisfy equations (4)-(6) and maximizes the operating profits of the incumbent firm in the intermediate good product line $j$, (ii) the RED decisions $x_{i j}$ are defined in equations (13), and the aggregate $R \mathcal{E} D$ is specified in equation (14), (iii) $C$ and $Y$ are given in equations (2) and (11), (iv) aggregate wage $w$ clears the labor markets at every instant, (v) interest rates $r$ satisfies the households' Euler equation, (vi) the share of unleveled industries $\mu$ satisfies (15), and (vii) all aggregate variables $(Y, C, Q, R, w)$ grow at the same $g$, which is given in (17).

\subsection{Impact of Knowledge Diffusion, $\delta$}

In this section, we discuss some theoretical predictions of the framework introduced above, which shed light on several empirical trends discussed in Section 2. Specifically, we focus on the effects of a decline in the intensity of knowledge diffusion on firms' innovation rates and their distribu- 
tional consequences. These effects, in turn, generate changes in markups, profits, and the labor share that are comparable to the observed trends. In the next section, we provide a discussion on why a decline in knowledge diffusion is a plausible explanation in light of the changes in the U.S. economy in recent decades.

We start with the following lemma that will form the basis of the main results.

Lemma 3 The following results hold in a BGP equilibrium.

1. Neck-and-neck firms have higher innovation intensity than laggard firms, i.e.,

$$
x_{-1}<x_{0}
$$

2. An increase in knowledge diffusion decreases innovation efforts. The decline is even more drastic for the neck-and-neck firms, i.e.,

$$
-1<\frac{d x_{0}}{d \delta}<\frac{d x_{-1}}{d \delta}<0
$$

Proof. See the appendix.

The first point of Lemma 3 is a standard result of step-by-step innovation models driven by the escape-competition effect-the attempt of neck-and-neck firms to get ahead of their competitor by intensely investing in innovation. The second point implies that a decline in knowledge diffusion has a positive effect on the innovation rates of follower and neck-and-neck firms, but more so for neck-and-neck firms. The reason is that the value of being a leader increases disproportionately as the exogenous risk of losing the positions declines. These relationships lead to the following corollary.

Corollary 1 The following result holds in a BGP equilibrium.

1. A decrease in knowledge diffusion increases market concentration:

$$
\frac{d \mu}{d \delta}<0
$$

Proof. See the appendix.

Corollary 1 describes the main predictions of the model when two BGPs with different knowledge diffusion rates are compared. The relatively larger increase in neck-and-neck firms' innovation rates in response to a decline in the intensity of knowledge diffusion results in an associated increase in the measure of unleveled sectors. This compositional shift forms the backbone of the theoretical predictions that we discuss in Section 4.4.

For the sake of analytical tractability, we clearly abstracted from important features of an economy that would potentially affect the dynamics of the model economy and its implications 
in regard to the stylized facts. One such feature is firm entry. Restricting the maximum number of technological gap differences to one also forgoes richer dynamics. In a complementary study [Akcigit and Ates (2019)], we incorporate these features along with some others to build a much richer framework and provide a quantitative analysis that also considers transitional dynamics. The extended model also allows us to run a head-to-head comparison of potential causes of the observed empirical trends in terms of their potency to explain those trends jointly. Acknowledging these caveats, we next turn to the theoretical predictions of the model.

\subsection{Reduction in Knowledge Diffusion and Empirical Facts 1-6}

Using the theoretical results above, now we are ready to generate the empirical predictions of our model.

\section{Fact 1. Market Concentration}

In our model, market competition is toughest when firms are in a neck-and-neck position, i.e., when the industry is in state $m=0$. Markups and profits vanish because of limit pricing, and sales are equalized. As a result, the aggregate Herfindahl-Hirschman index (HHI) can be summarized as follows:

$$
\begin{aligned}
H H I & =\mu \times\left[(100 \%)^{2}+(0 \%)^{2}\right]+(1-\mu) \times\left[(50 \%)^{2}+(50 \%)^{2}\right] \\
& =0.5+0.5 \mu
\end{aligned}
$$

Our model implies that the HHI, the key measure of market concentration, increases in the measure of unleveled industries $(\mu)$. Recall that the BGP expression of the unleveled industries is

$$
\mu=\frac{2 x_{0}}{2 x_{0}+x_{-1}+\delta} \text {. }
$$

From Corollary 1, a decrease in knowledge diffusion increases market concentration through a direct and an indirect channel. First, a reduction in $\delta$ reduces the frequency at which followers learn from the leaders, hence, market concentration increases. Second, reduced knowledge diffusion increases the return to being the market leader. Neck-and-neck firms are much closer to becoming a leader than a follower who needs two innovations to become a leader. Therefore, an increase in the return to being a leader gives a bigger incentive to neck-and-neck firms, which in turn expands the share of unleveled industries, hence, the market concentration, i.e.,

$$
\frac{d(H H I)}{d \delta}<0
$$




\section{Fact 2. Markups}

In this model, markups are positive only when a firm has a strict advantage over its rival, i.e., $m_{i}=1$. Therefore, the average markup in this economy is

$$
\begin{aligned}
\text { Average_markup } & =\mu \times(\lambda-1)+(1-\mu) \times 0 \\
& =\mu \times(\lambda-1) .
\end{aligned}
$$

This expression shows that the average markup is proportional to the market concentration in the economy. Using Corollary 1.1, we conclude that the average markup increases when knowledge diffusion decreases, i.e.,

$$
\frac{d(\text { Average_markup })}{d \delta}<0 .
$$

\section{Fact 3. Profit Share of GDP}

Another empirical fact that the the model can directly explain is the rise in the profit share of GDP. Recall that the profits in unleveled sectors are $\left(1-\lambda^{-1}\right) Y$ and in leveled industries they are 0 . Therefore, the aggregate profit share is simply

$$
\text { Profit/GDP }=\mu \times\left(1-\frac{1}{\lambda}\right) \text {. }
$$

We again see that a rise in market concentration increases the share of GDP that is accrued by the business owners. Hence, a reduction in knowledge diffusion also causes a rise in the profit share of GDP, i.e.,

$$
\frac{d(\text { Profit } / G D P)}{d \delta}<0
$$

\section{Fact 4. Labor Share}

In our model, labor is the only input for production. When business owners generate some additional gains as a fraction of the output, it comes at the expense of reduced labor compensation. Therefore, markups and labor share go in opposite directions. More formally, the labor share in the above economy is

$$
\begin{aligned}
\text { Labor_share } & =(1-\mu) \times 1+\mu \times \frac{1}{\lambda} \\
& =1-\mu \times\left(1-\frac{1}{\lambda}\right)
\end{aligned}
$$


which is again defined as $\omega$ as in equation (10). The labor share is $100 \%$ in leveled industries and $1 / \lambda$ in unleveled industries. Therefore, this expression shows that the labor share decreases in market concentration and increases in the level of knowledge diffusion, as summarized by the following expression:

$$
\frac{d(\text { Labor_share })}{d \delta}>0 \text {. }
$$

\section{Fact 5. Market Concentration and Labor Share}

Our model has an interesting prediction on the relationship between productivity and labor share. In the same industry, firms' wage bill as share of sales decreases when they become more productive. Consider a leveled sector. When firms are neck-and-neck, the labor share is simply $100 \%$, as they do not generate any profits. Yet once one of the firms innovates and becomes more productive, the labor share declines to $1 / \lambda$. Therefore, market concentration and labor share are negatively correlated:

$$
\text { Labor_share }\left(m_{j}=1\right)<\text { Labor_share }\left(m_{j}=0\right) \text {. }
$$

\section{Fact 6. Productivity Gap between Leaders and Followers}

Another interesting feature of our model is the link between relative productivities $\left(q_{i} / q_{-i}\right)$ and knowledge diffusion $(\delta)$. The productivity of the market leader relative to the follower is 1 in leveled industries and $\lambda$ in unleveled industries. Therefore, the average relative productivity can be expressed as

$$
\begin{aligned}
\text { Average_productivity_gap } & =\mu \times \lambda+(1-\mu) \\
& =1+\mu \times(\lambda-1) .
\end{aligned}
$$

This expression, together with Corollary 1.1, implies that when knowledge diffusion slows down, the productivity gap between the leaders and followers open up. Therefore,

$$
\frac{d(\text { Average_productivity_gap })}{d \delta}<0
$$

\subsection{Remaining Empirical Facts 7-10}

In the introduction of this paper, we listed four more empirical facts in the U.S. data. Two of those facts

Fact 7 Firm entry rate has declined. 
Fact 8 The share of young firms in economic activity has declined.

were related to entrants. Our model is silent on these facts, as we abstracted from free entry in order to keep the model analytically tractable and mostly focused on the competition between two incumbents. However, we can already develop some intuitions on the implications of free entry in this framework. Empirically, it is well known that new firms start small and some manage to grow over time. To capture this, we can think of a framework where entrants replace followers $\left(m_{i}=-1\right)$ with probability $\mu$ or neck-and-neck firms $\left(m_{i}=0\right)$ with probability $1-\mu$. Since entrants would be forward looking, they would directly be influenced by those forces that impact the market concentration. In particular, the implication of reduced knowledge diffusion (i.e., a decline in $\delta$ ) would increase market concentration $\mu$, which implies that a new entrant is much more likely to compete against a dominant market $\left(m_{i}=1\right)$, which would discourage new firm creation. This would also imply that the economic activity by young firms would also decrease.

The remaining two empirical facts

Fact 9 Job reallocation has slowed down.

Fact 10 The dispersion of firm growth has decreased.

concern the average growth rate of incumbents. Our model has the potential to explain these facts as well. Note that the change in the growth rate dynamics of firms is determined by two forces: (i) the composition of industries $(\mu)$ and (ii) the innovation incentives in each of those industries. In particular, a decrease in knowledge diffusion encourages both followers and neck-and-neck firms to invest more to innovate and become the market leader since the value of market leadership increases. This creates a positive incentive effect. However, reduction in knowledge diffusion implies that more sectors go into an unleveled state where firms invest less in innovation. This generates a negative composition effect. Hence, the overall response of firm growth and job reallocation depends on the quantitative magnitudes of each of these forces.

Aggregate productivity growth. Although not a primary focus of this work, we find a discussion of the model's implication for productivity growth worthwhile. Similar to the last two facts, aggregate productivity growth in this model would be determined by the combination of incentive and composition effects. A decline in the intensity of knowledge diffusion would exert both a positive force on aggregate growth by stimulating innovation of neck-and-neck firms and a negative force by causing the share of unleveled sectors to increase. In the BGP, the direction of the combined effect of the negative force through $x_{0}$ and the positive force through $\mu$ would be ambiguous, as revealed by equation (17).

While a comparison that zeros in on the BGP yields an indeterminacy result, reflecting on the transition path can give a little more insight. In the model, endogenous firm decisions cause the compositional shifts in the economy. Therefore, in response to a decline in the intensity of 
knowledge diffusion, we would expect an initial rise in the growth rate of aggregate productivity driven by higher innovation efforts by firms in leveled sectors, unless the share of those sectors in the economy is arbitrarily small. However, as the sectoral composition of the economy shifts to unleveled sectors as a result of successful innovation by neck-and-neck firms, the growth rate of aggregate productivity would subsequently decline because the leading firms have no incentive to innovate. ${ }^{24}$ As a result, a decline in knowledge diffusion would generate a humpshaped pattern in aggregate productivity growth over time. Interestingly, the short stint of higher productivity growth in the United States between roughly the mid-1990s and mid-2000s, which many economists consider to be a consequence of diffusion of ICT throughout the economy, is followed by a growth decline. Our model can provide an avenue to analyze this intriguing pattern.

\section{Discussion on Knowledge Diffusion and Taking Stock}

Our theoretical analysis underscores both the potential and the limitations of the simplified stepby-step innovation framework. As to its potential, we demonstrated that even a fairly standard version of this framework is able to capture qualitatively 6 of the 10 stylized facts regarding declining business dynamism. These results crucially depend on the interplay of incentive and composition effects. However, the direction of the combined effect is ambiguous when it comes to Facts 9 and 10, calling for a quantitative investigation of their relative magnitudes. Moreover, several aspects from which we abstracted for the sake of analytical tractability render the model mute on some other salient empirical observations such as the secular trend in the firm entry rate. These outcomes emphasize the need for a richer quantitative framework for analyzing declining business dynamism in the United States.

In our investigation, we examined declining U.S. business dynamism in light of a specific channel-namely the knowledge diffusion margin. The model-based responses of variables of interest to a decline in the intensity of knowledge diffusion strongly parallel their empirical counterparts, indicating that this margin is a very plausible candidate for the driving force behind the stylized facts. This finding raises the natural follow-up question: What does this reduced form parameter represent? We speculate four possible channels, which possibly interact with each other as well, that could be driving a decline in the intensity of knowledge diffusion in the U.S. economy: (i) the increasingly data-dependent nature of production, (ii) regulations that favor established firms, (iii) increased off-shoring of production abroad, and (iv) anti-competitive (ab)use of intellectual property. Next, we reflect on each of these channels.

A plausible story is that to the extent that tacit knowledge and big proprietary data play a larger role in the production process, established incumbents become more immune to competi-

\footnotetext{
${ }^{24}$ This effect occurs even if leaders are allowed to open up the gap with their competitors more than one step.
} 
tion from follower firms by protecting their data-dependent processes. ${ }^{25}$ As stressed in Section 3, several studies highlight the particular dynamics of ICT- or digitally-intensive sectors [e.g., Bessen (2017); Calligaris et al. (2018)]. Besides, Furman and Seamans (2018), Jones and Tonetti (2018), Arrieta-Ibarra et al. (2018) all focus on the increasing importance of data in the economy, and as Brynjolfsson et al. (2017) claim, there is reason to expect its part to grow in the not-too-distant future. ${ }^{26}$ As highlighted in The Economist (2017a), the data-dependent production processes allow large and established firms to exploit data-network effects-more data help them efficiently expand the customer base, which generates more data that help improve services, which in turn attracts more customers. With little trading of data, these companies can keep the data in house, limiting the flow of knowledge to follower or entrant firms. ${ }^{27}$ Moreover, an indirect yet no less interesting channel through which technological advances may favor large firms is described by Begenau et al. (2018). The authors assert that the use of big data in financial markets reduces the cost of capital for large firms, which are in an advantageous position to generate such data.

The regulatory framework can also weigh on knowledge diffusion directly or indirectly. Grullon et al. (2017) highlight a weakening enforcement of anti-trust law, with the application becoming more lenient toward large firms. Their findings resonate with several studies in the corporate law literature that agree with such weakening, especially in recent decades [Crane (2012), Harty et al. (2012), Wollman (2018), see also Section 3]. With increased consolidation of activity in their hands, large conglomerates may potentially find it easier to defend their turf, substantially decreasing the chances for small firms to learn from and catch up with them. The finding of Bessen (2016) on the increasing importance of lobbying and political rent seeking speaks to this possibility. Moreover, regulatory frameworks can indirectly create barriers for the dissemination of knowledge. For instance, increased and inefficient use of occupational licensing and non-compete laws could weigh on job mobility and reallocation [Marx et al. (2009) and Furman and Giuliano (2016)], which in turn prevents an efficient flow of knowledge through the economy.

A third possibility that could drive a potential decline in knowledge diffusion intensity is

\footnotetext{
${ }^{25}$ In a recent Harvard Business Review post, James Bessen and Walter Frick argue that increasing use of software benefit larger firms disproportionately more, helping them dominate their industries (https://hbr.org/2018 /11/how-software-is-helping-big-companies-dominate). See also the Wall Street Journal article for examples of how new technologies help large firms to better exploit economies of scale (https://www.wsj.com/articles/the-problemwith-innovation-the-biggest-companies-are-hogging-all-the-gains-1531680310).

${ }^{26}$ In a recent study, Jones and Tonetti (2018) approach the increasing importance of data economics from a novel angle-namely the optimal allocation of property rights for customer data. The authors claim that firms' attempt to hoard proprietary data for their own use in fear of potential "creative destruction" leads to an inefficient use of nonrival data. Arrieta-Ibarra et al. (2018) highlight another concern with the market power of data-owning firms. The authors argue that the monopsony position of firms collecting consumer data may depress the value of data and productivity gains from its use.

27 Vives (2011) and Bergemann et al. (2015) provide theoretical underpinnings of the interaction between private information and market power-i.e., the ability to affect prices-in the context of supply- and demand-schedule competition, respectively.
} 
the increasing use of off-shore production. ${ }^{28}$ A large literature has argued that geographical proximity to the knowledge source plays a very crucial role in knowledge diffusion [Jaffe et al. (1993), Audretsch and Feldman (1996), Porter (2000)]. If the ability to utilize spillovers from other firms depends on the geographical proximity to these knowledge-source firms, it would be natural to expect a reduction in knowledge diffusion from leaders to followers in the United States if the leaders do most of their economic activity abroad. This would in turn depress domestic flow of knowledge.

Another culprit for a declining knowledge diffusion intensity could be the use of patent protection by large firms through the creation of patent thickets. To the extent that these thickets are exclusively used for defensive purposes, they may undermine the activity of followers, as they form, in words of Shapiro (2001), "a dense web of overlapping intellectual property rights that a company must hack its way through in order to actually commercialize new technology." 29 For instance, Hall et al. (2015) find that thickets work as a barrier to entry into technology sectors in the United Kingdom. ${ }^{30}$ Large firms also frequently buy patents of competitors before they realize the full potential of knowledge spillovers. Using patent and reassignment databases maintained by the United States Patent and Trademark Office (USPTO), we provide evidence that this may indeed play a role in declining knowledge diffusion.

Figure 12a demonstrates that since the mid-1980s, there has been a steady surge in the share of reassigned patents held by the largest one percent of buyers of patents. These findings resonate with Grullon et al. (2017) — who argue that merger and acquisition activity is one contributor to higher market concentration-and with Gao et al. (2013)_who claim that one reason for the decline in the number of initial public offerings in the past two decades is that startups have become likelier to sell their assets to larger companies. In addition, we show that there has also been a parallel surge in patent concentration. Figure $12 \mathrm{~b}$ reveals that the share of patents applied for by the top one percent of firms with the largest patent stocks has substantially increased. This empirical contribution from the USPTO data to the discussion of declining business dynamism supports our mechanism (distortions in knowledge flow between frontier and follower firms) and its implications for observed trends. The nice feature of our proposed framework is that it provides a theoretical link between Figure 12a and Figure 12b via endogenous optimal decisions of forward-looking firms.

To be sure, several other factors could be responsible for declining U.S. business dynamism.

\footnotetext{
${ }^{28}$ We thank Pol Antràs for this interesting insight.

29 Independent estimates suggest that there are about 250,000 patents related to a smartphone today (https://www.bbc.com/news/business-15343549).

30 Similarly, Hall and Ziedonis (2001) document that after the mid-1980s, large firms in the U.S. semiconductor industry have strived for expanding their patent portfolios to protect themselves against potential holdup problems. The authors argue that this intensified strategic race for portfolios was the result of a pro-patent legal shift in the U.S. with the formation of a centralized appellate court (the Court of Appeals for the Federal Circuit) in 1982. For a more recent account of this shift toward stronger patent rights, see Galasso and Schankerman (2010), who study the effects of the new regime on the duration of licensing negotiations.
} 


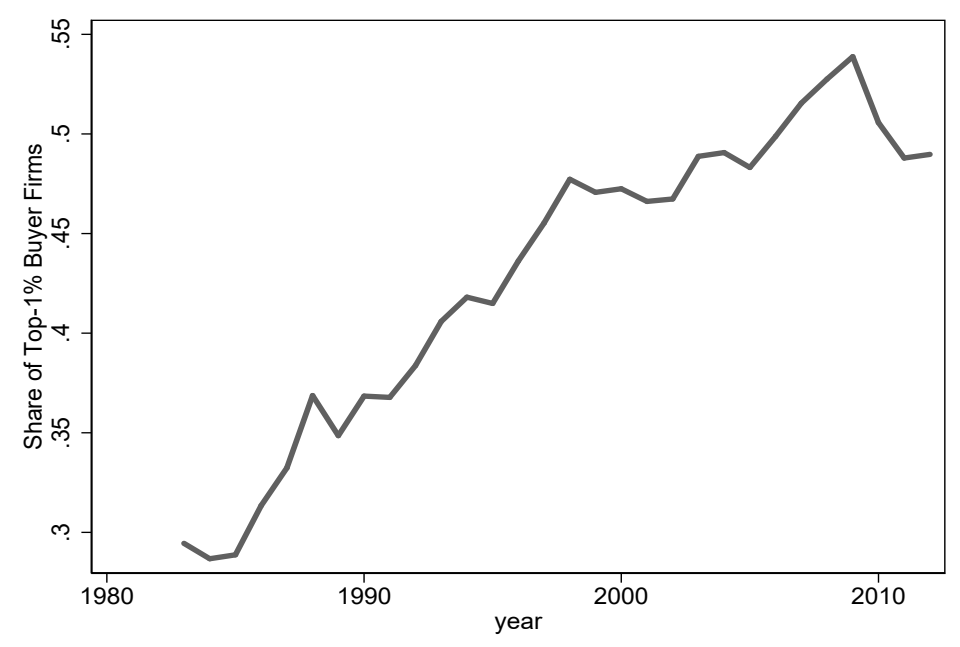

A) Reassignment

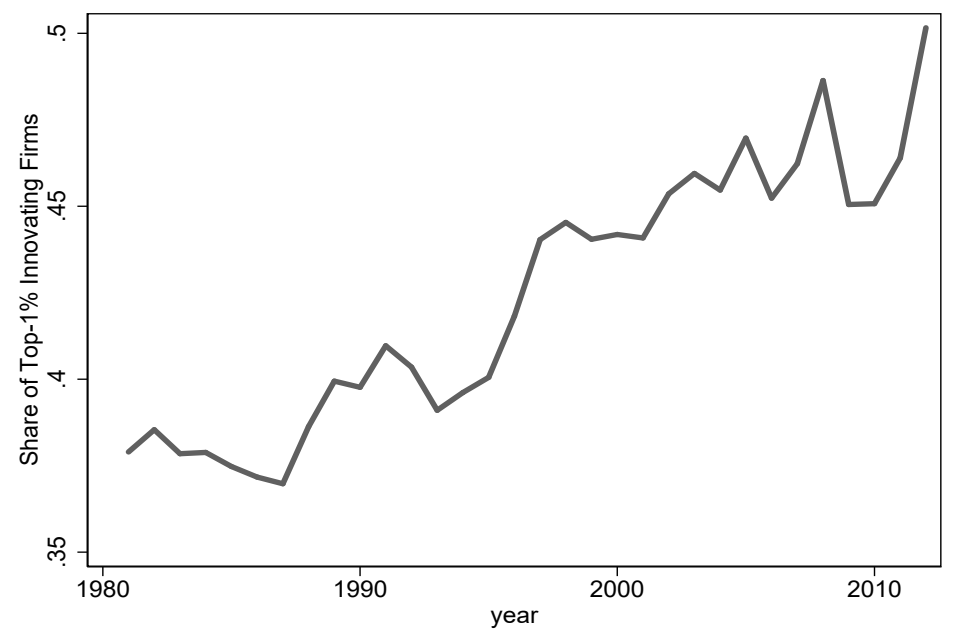

в) Application

Source: Authors' own calculation using U.S. Patent and Trademark Office data

Figure 12: Reassignment and Registry of Patents

A natural next step in this line of research would be the comparative analysis of those factors, which would necessitate a richer quantitative framework. However, even through the lens of the simplified model, we can assess the limited ability of some factors to jointly speak to all stylized facts. For instance, there has been a steady decline in effective corporate tax rates in the United States, which may likely have contributed to the rise of profit shares. Yet, in the context of the step-by-step innovation models with entry, such a shift would likely generate a stronger incentive for firm entry, going against Fact $7 .{ }^{31}$ Of course, various other alternatives proposed in

\footnotetext{
${ }^{31}$ For a version of step-by-step models with endogenous firm entry, see Akcigit et al. (2018). In their quantitative analysis, the authors show that entry responds positively across the board to higher R\&D tax incentives for incumbent firms. It is straightforward to see that a decline in corporate tax rates would generate a similar effect.
} 
the literature require a more in-depth investigation, and we will concentrate on those alternatives in future research.

\section{Conclusion}

In this paper, we present both a review of stylized facts on declining business dynamism and a theoretical framework suitable for a joint analysis of these empirical observations. Accounting for the nexus of competition and firm incentives, the step-by-step innovation framework provides a useful ground to explore business dynamics through the lens of endogenous firm decisions and the resulting compositional changes. Our analysis demonstrates that even a simple version of this rich framework is able to replicate a number of empirical trends associated with declining business dynamism. However, the analysis also highlights that the examination of the decades long shifts in the U.S. economy is a matter of quantitative work. Such analysis would need to establish a tighter link between the model and the data while also accounting for the transitional dynamics of the economy. This is the next step in our research agenda.

The ultimate question is, what factors have led to a decline in business dynamism? Here we address the potential role knowledge diffusion may have played. We show analytically that a decline in the intensity of knowledge diffusion from frontier to laggard firms generates aggregate responses in line with empirical trends. Some new evidence that we obtain from the USPTO patent database supports the view that a distortion in this margin has emerged. It is of course likely that several other factors including structural or policy-induced changes may have contributed to the observed shifts in the economy. Once again, the study of these other margins warrants a richer and quantitative framework and is the central subject of our research agenda.

Finally, a good understanding of the underlying causes of declining U.S. business dynamism is crucial to form the appropriate policy response. Is a shift in the technological nature of the economy behind the observed trends? Is there a change in policy (e.g., enforcement of antitrust policies) that has motivated firms to take actions that endogenously lead to higher concentration in product markets? These widely debated concerns call for a framework that enables a comparative study of alternative explanations. Yet, first and foremost, public policy necessitates an evaluation of the implications of declining business dynamism on income and welfare-another fruitful direction for further research. 


\section{References}

Acemoglu, Daron and Pascual Restrepo, "Robots and Jobs: Evidence from US Labor Markets," 2017. National Bureau of Economic Research Working Paper 23285.

- and Ufuk Akcigit, "Intellectual Property Rights Policy, Competition and Innovation," Journal of the European Economic Association, 2012, 10 (1), 1-42.

Aghion, Philippe, Christopher Harris, and John Vickers, "Competition and Growth with Stepby-step Innovation: An Example," European Economic Review, 1997, 41 (3-5), 771-782.

_ , , , Peter Howitt, and John Vickers, "Competition, Imitation and Growth with Step-by-Step Innovation," Review of Economic Studies, 2001, 68 (3), 467-492.

_, Nick Bloom, Richard Blundell, Rachel Griffith, and Peter Howitt, "Competition and Innovation: An Inverted-U Relationship," Quarterly Journal of Economics, 2005, 120 (2), 701-728.

_ , Ufuk Akcigit, Antonin Bergeaud, Richard Blundell, and David Hemous, "Innovation and Top Income Inequality," The Review of Economic Studies, 2018, p. forthcoming.

Ahmad, Nadim, Jennifer Ribarsky, and Marshall Reinsdorf, "Can Potential Mismeasurement of the Digital Economy Explain the Post-crisis Slowdown in GDP and Productivity Growth?," 2017. OECD Statistics Working Papers, 2017/09.

Akcigit, Ufuk and Qingmin Liu, "The Role of Information in Innovation and Competition," Journal of the European Economic Association, 2016, 14 (4), 828-870.

- and Sina T. Ates, "What Happened to U.S. Business Dynamism?," 2019. National Bureau of Economic Research Working Paper 25756.

- and William R. Kerr, "Growth through Heterogeneous Innovations," Journal of Political Economy, 2018, 126 (4), 1374-1443.

_ , Harun Alp, and Michael Peters, "Lack of Selection and Limits to Delegation: Firm Dynamics in Developing Countries," 2015. National Bureau Economic Research Working Paper 21905.

_, Sina T. Ates, and Giammario Impullitti, "Innovation and Trade Policy in a Globalized World," 2018. National Bureau of Economic Research Working Paper 24543.

Akerlof, George A., Andrew K. Rose, and Janet L. Yellen, "Job Switching and Job Satisfaction in the U.S. Labor Market," Brookings Papers on Economic Activity, 1988, 19 (2), 495-594.

Aksoy, Yunus, Henrique S. Basso, Ron P. Smith, and Tobias Grasl, "Demographic Structure and Macroeconomic Trends," American Economic Journal: Macroeconomics, 2018. forthcoming.

Andrews, Dan, Chiara Criscuolo, and Peter N. Gal, "Frontier Firms, Technology Diffusion and Public Policy," 2015. OECD Productivity Working Paper No. 2.

_, , , and _, "The Best versus the Rest: The Global Productivity Slowdown, Divergence across Firms and the Role of Public Policy," 2016. OECD Productivity Working Paper 5/2016.

Arrieta-Ibarra, Imanol, Leonard Goff, Diego Jimènez-Hernández, Jaron Lanier, and E. Glen Weyl, "Should We Treat Data as Labor? Moving beyond "Free"," AEA Papers and Proceedings, 2018, 108, 38-42. 
Audretsch, David B. and Maryann P. Feldman, "R\&D Spillovers and the Geography of Innovation and Production," American Economic Review, 1996, 86 (3), 630-640.

Autor, David, David Dorn, Lawrence F. Katz, Christina Patterson, and John Van Reenen, “Concentrating on the Fall of the Labor Share," American Economic Review, 2017, 107 (5), 180-85.

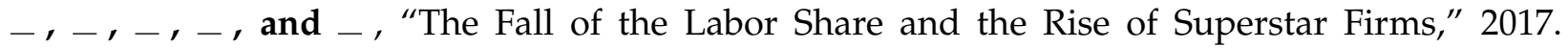
National Bureau of Economic Research Working Paper 23396.

Ayyagari, Meghana, Asli Demirguc-Kunt, and Vojislav Maksimovic, "Who Are America's Star Firms?," 2018. Policy Research Working Paper 8534.

Azar, José and Xavier Vives, “Oligopoly, Macroeconomic Performance, and Competition Policy," 2018. CESifo Working paper 7189.

_ , Ioana Marinescu, and Marshall I. Steinbaum, “Labor Market Concentration," 2017. National Bureau of Economic Research Working Paper 24147.

Baker, Jonathan B., "Economics and Politics: Perspectives on the Goals and Future of Antitrust," Fordham Law Review, 2012, 81, 2175.

Barkai, Simcha, "Declining Labor and Capital Shares," 2017. mimeo.

Begenau, Juliane, Maryam Farboodi, and Laura Veldkamp, "Big Data in Finance and the Growth of Large Firms," Journal of Monetary Economics, 2018, 97, 71-87.

Bergemann, Dirk, Tibor Heumann, and Stephen Morris, "Information and Market Power," 2015. Cowles Foundation Discussion Papers No. 2017.

Bessen, James E., "Accounting for Rising Corporate Profits: Intangibles or Regulatory Rents?," 2016. Law \& Economics Paper Series 16-18, Boston University School of Law.

_ , "Information Technology and Industry Concentration," 2017. Law \& Economics Paper Series 17-41, Boston University School of Law.

Bettendorf, Leon, Gerdien W. Meijerink, and Gerrit H. van Heuvelen, "The Contribution of Small Firms to the Dutch Productivity Frontier," 2018. The 7th CompNet Annual Conference: Economic Growth, Trade and Productivity Dispersion.

Binjens, Gert and Jozef Konings, "Declining Business Dynamism," 2018. CEPR Discussion Papers DP12165.

Blonigen, Bruce A. and Justin R. Pierce, "Evidence for the Effects of Mergers on Market Power and Efficiency," 2016. National Bureau Economic Research Working Paper 22750.

Bloom, Nicholas, Charles I. Jones, John Van Reenen, and Michael Webb, "Are Ideas Getting Harder to Find?," 2017. National Bureau Economic Research Working Paper 23782.

_, Rachel Griffith, and John Van Reenen, "Do R\&D Tax Credits Work? Evidence from a Panel of Countries 1979-1997," Journal of Public Economics, 2002, 85 (1), 1-31.

Blundell, Richard, Rachel Griffith, and Frank Windmeijer, "Individual Effects and Dynamics in Count Data Models," Journal of Econometrics, 2002, 108 (1), 113-131. 
Boehm, Christoph E., Aaron Flaaen, and Nitya Pandalai-Nayar, "Multinationals Offshoring, and the Decline of U.S. Manufacturing," 2017. Center for Economic Studies, U.S. Census Bureau, Working Papers 17-22.

Bravo-Biosca, Albert, Chiara Criscuolo, and Carlo Menon, "What Drives the Dynamics of Business Growth?," 2013. OECD Science, Technology and Industry Policy Papers No. 1.

Brynjolfsson, Erik and Andrew McAfee, The Second Machine Age: Work, Progress, and Prosperity in A Time of Brilliant Technologies, WW Norton \& Company, 2014.

_, Daniel Rock, and Chad Syverson, "Artificial Intelligence and the Modern Productivity Paradox: A Clash of Expectations and Statistics," 2017. National Bureau of Economic Research Working Paper 24001.

Budd, Christopher, Christopher Harris, and John Vickers, "A Model of the Evolution of Duopoly: Does the Asymmetry between Firms Tend to Increase or Decrease?," Review of Economic Studies, 1993, 60 (3), 543-573.

Calligaris, Sara, Chiara Criscuolo, and Luca Marcolin, "Mark-ups in the Digital Era," 2018. OECD Working Paper 2018-10.

Council of Economic Advisors, “Benefits of Competition and Indicators of Market Power," 2016. Issue brief.

Crane, Daniel A., "Has the Obama Justice Department Reinvigorated Antitrust Enforcement," Stanford Law Review Online, 2012, 65, 13.

Criscuolo, Chiara, Peter N. Gal, and Carlo Menon, "The Dynamics of Employment Growth," 2014. OECD Science, Technology and Industry Policy Papers No. 14.

Crouzet, Nicolas and Janice Eberly, "Understanding Weak Capital Investment: The Role of Market Concentration and Intangibles," 2018. Jackson Hole Economic Policy Symposium.

Cunningham, Colleen, Song Ma, and Florian Ederer, "Killer Acquisitions," Academy of Management Proceedings, 2018, (1).

Davis, Steven J. and John Haltiwanger, "Labor Market Fluidity and Economic Performance," 2014. National Bureau of Economic Research Working Paper 20479.

De Loecker, Jan and Jan Eeckhout, "The Rise of Market Power and The Macroeconomic Implications," 2017. National Bureau of Economic Research Working Paper 23687.

_ and _ , "Global Market Power," 2018. National Bureau of Economic Research Working Paper 24768.

Decker, Ryan A., John C. Haltiwanger, Ron S. Jarmin, and Javier Miranda, "Changing Business Dynamism and Productivity: Shocks vs. Responsiveness," 2018. National Bureau Economic Research Working Paper 24236.

_, John Haltiwanger, Ron S. Jarmin, and Javier Miranda, "Declining Business Dynamism: What We Know and the Way Forward," American Economic Review: Papers \& Proceedings, 2016, 106 (5), 203-07.

Diez, Federico, Daniel Leigh, and Suchanan Tambunlertchai, "Global Market Power and Its Macroeconomic Implications," 2018. International Monetary Fund Working Papers 18/137. 
Eggertsson, Gauti B., Jacob A. Robbins, and Ella Getz Wold, "Kaldor and Piketty's Facts: The Rise of Monopoly Power in the United States," 2018. National Bureau of Economic Research Working Paper 24287.

Elsby, Michael, Bart Hobijn, and Aysegul Sahin, "The Decline of the U.S. Labor Share," 2013. Federal Reserve Bank of San Francisco, Working Paper 2013-27.

Farhi, Emmanuel and François Gourio, "Accounting for Macro-Finance Trends: Market Power, Intangibles, and Risk Premia," 2018. National Bureau of Economic Research Working Paper 25282.

Fernald, John, "Productivity and Potential Output before, during, and after the Great Recession," 2014. National Bureau of Economic Research Working Paper 20248.

Fernald, John G. and Charles I. Jones, "The Future of U.S. Economic Growth," American Economic Review, 2014, 104 (5), 44-49.

Furman, Jason and Laura Giuliano, "New Data Show That Roughly One-Quarter of U.S. Workers Hold an Occupational License," 2016. https:/ /obamawhitehouse.archives.gov/blog/2016/06/17/new-data-show-roughly-onequarter-us-workers-hold-occupational-license.

_ and Peter Orszag, "Slower Productivity and Higher Inequality: Are They Related?," 2018. Working Paper 2018-4, Peterson Institute for International Economics.

- and Robert Seamans, "AI and the Economy," 2018. National Bureau of Economic Research Working Paper 24689.

Galasso, Alberto and Mark Schankerman, "Patent Thickets, Courts, and the Market for Innovation," The RAND Journal of Economics, 2010, 41 (3), 472-503.

Gao, Xiaohui, Jay R. Ritter, and Zhongyan Zhu, "Where Have All the IPOs Gone?," Journal of Financial and Quantitative Analysis, 2013, 48 (6), 1663-1692.

Goldschlag, Nathan and Alex Tabarrok, "Is Regulation to Blame for the Decline in American Entrepreneurship?," Economic Policy, 2018, 33 (93), 5-44.

- and Javier Miranda, "Business Dynamics Statistics of High Tech Industries," 2016. Working Papers 16-55, Center for Economic Studies, U.S. Census Bureau.

Gordon, Robert J., "Is U.S. Economic Growth Over? Faltering Innovation Confronts the Six Headwinds," 2012. National Bureau of Economic Research Working Paper 18315.

_ , The Rise and Fall of American Growth: The U.S. Standard of Living since the Civil War, Princeton University Press, 2016.

Gort, Michael and Steven Klepper, "Time Paths in the Diffusion of Product Innovations," The Economic Journal, 1982, 92 (367), 630-653.

Gourio, François, Todd Messer, and Michael Siemer, "What Is the Economic Impact of the Slowdown in New Business Formation?," Chicago Fed Letter, 2014, (Sep).

_ , _ , and _ , "Firm Entry and Macroeconomic Dynamics: A State-Level Analysis," American Economic Review, May 2016, 106 (5), 214-18. 
Griliches, Zvi, "Patent Statistics as Economic Indicators: A Survey," Journal of Economic Literature, 1990, 28 (4), 1661-1707.

Grullon, Gustavo, Yelena Larkin, and Roni Michaely, “Are U.S. Industries Becoming More Concentrated?," 2017. mimeo.

Gutiérrez, Germán and Thomas Philippon, "Investment-less Growth: An Empirical Investigation," 2016. National Bureau of Economic Research Working Paper 22897.

_ and _ , "Declining Competition and Investment in the U.S.," 2017. National Bureau of Economic Research Working Paper 23583.

Hagedorn, Marcus and Iourii Manovskii, "Job Selection and Wages over the Business Cycle," The American Economic Review, 2013, 103 (2), 771-803.

Hall, Bronwyn H., "R\&D Tax Policy During the 1980s: Success or Failure?," Tax Policy and the Economy, 1992, 7, 1-36.

- and John Van Reenen, "How Effective Are Fiscal Incentives for R\&D? A Review of the Evidence," Research Policy, 2000, 29 (4), 449-469.

- and Rosemarie H. Ziedonis, "The Patent Paradox Revisited: An Empirical Study of Patenting in the U.S. Semiconductor Industry, 1979-1995," The RAND Journal of Economics, 2001, 32 (1), $101-128$.

_ , Christian Helmers, and Georg von Graevenitz, "Technology Entry in the Presence of Patent Thickets," 2015. National Bureau of Economic Research Working Paper 21455.

Hall, Robert E., "New Evidence on Market Power, Profit, Concentration, and the Role of MegaFirms in the U.S. Economy," 2018. Standofrd University, mimeo.

Haltiwanger, John, Ron S. Jarmin, and Javier Miranda, "Who Creates Jobs? Small versus Large versus Young," The Review of Economics and Statistics, 2013, 95 (2), 347-361.

-, Stefano Scarpetta, and Helena Schweiger, "Cross Country Differences in Job Reallocation: The Role of Industry, Firm Size and Regulations," Labour Economics, 2014, 26, 11-25.

Harris, Christopher and John Vickers, "Perfect Equilibrium in a Model of a Race," Review of Economic Studies, 1985, 52 (2), 193-209.

_ and _ , "Racing with Uncertainty," Review of Economic Studies, 1987, 54 (1), 1-21.

Harty, Ronan, Howard Shelanski, and Jesse Solomon, "Merger Enforcement across Political Administrations in the United States," Concurrences-Competition Law Review, 2012, 2, 1-9.

Hopenhayn, Hugo, Julian Neira, and Rish Singhania, "From Population Growth to Firm Demographics: Implications for Concentration, Entrepreneurship and the Labor Share," 2018. National Bureau of Economic Research Working Paper 25382.

Jaffe, Adam B., Manuel Trajtenberg, and Rebecca Henderson, "Geographic Localization of Knowledge Spillovers as Evidenced by Patent Citations," Quarterly Journal of Economics, 1993, 108 (3), 577-598.

Jones, Charles and Christopher Tonetti, "Nonrivary and the Economics of Data," 2018. Standofrd University, mimeo. 
Karabarbounis, Loukas and Brent Neiman, "The Global Decline of the Labor Share," Quarterly Journal of Economics, 2013, 129 (1), 61-103.

_ and _ , "Accounting for Factorless Income," 2018. National Bureau of Economic Research Working Paper 24404.

Karahan, Fatih, Benjamin Pugsley, and Aysegul Sahin, "Demographic Origins of the Startup Deficit," 2016. New York Fed, mimeo.

Kaymak, Baris and Immo Schott, "Corporate Tax Cuts and the Decline of the Labor Share," 2018. Society for Economic Dynamics, 2018 Meeting Papers 943.

Kehrig, Matthias and Nicolas Vincent, "The Micro-Level Anatomy of the Labor Share Decline," 2018. National Bureau of Economic Research Working Paper 25275.

Khan, Lina M., “Amazon's Antitrust Paradox," Yale Law Journal, 2016, 126, 710-805.

Kortum, Samuel, "Research, Patenting, and Technological Change," Econometrica, 1997, 65 (6), 1389-1420.

Lawrence, Robert Z., "Recent Declines in Labor's Share in U.S. Income: A Preliminary Neoclassical Account," 2015. National Bureau of Economic Research Working Paper 21296.

Lynn, Barry C., Cornered: The New Monopoly Capitalism and The Economics of Destruction, John Wiley \& Sons Hoboken, NJ, 2010.

Marx, Matt, Deborah Strumsky, and Lee Fleming, "Mobility, Skills, and the Michigan NonCompete Experiment," Management Science, 2009, 55 (6), 875-889.

Nekarda, Christopher J. and Valerie A. Ramey, "The Cyclical Behavior of the Price-Cost Markup," 2013. National Bureau of Economic Research Working Paper 19099.

Nordhaus, William D., "Are We Approaching an Economic Singularity? Information Technology and the Future of Economic Growth," 2015. National Bureau of Economic Research Working Paper 21547.

OECD, “Market Concentration," 2018. Issues Paper by the Secretariat.

_ , "Market Concentration - Note by the BIAC," 2018. Hearing on Market Concentration.

_ , "Market Concentration - Note by the United States," 2018. Hearing on Market Concentration.

Porter, Michael E., "Location, Competition, and Economic Development: Local Clusters in a Global Economy," Economic Development Quarterly, 2000, 14 (1), 15-34.

Shapiro, Carl, "Navigating the Patent Thicket: Cross Licenses, Patent Pools, and Standard Setting," in "Innovation Policy and the Economy, Volume 1" NBER Chapters, National Bureau of Economic Research, Inc., October 2001, pp. 119-150.

Stiglitz, Joseph, "Inequality, Stagnation, and Market Power," 2017. The Roosevelt Institute.

Syverson, Chad, "Challenges to Mismeasurement Explanations for the U.S. Productivity Slowdown," Journal of Economic Perspectives, 2017, 31 (2), 165-86.

The Economist, "Business in America: Too Much of a Good Thing," September 2016.

_ , "Fuel of the Future: Data is Giving Rise to a New Economy," May 2017. 
_ , "Regulating the Internet Giants: The World's Most Valuable Resource Is No Longer Oil, but Data," May 2017.

_ , "Competition is Withering on Both Sides of the Atlantic," June 2018.

_ , "Into the Danger Zone: American Tech Giants Are Making Life Tough for Startups," June 2018.

_ , “Special Report: Trustbusting in the 21st Century," November 2018.

Traina, James, "Is Aggregate Market Power Increasing? Production Trends Using Financial Statements," 2018. Stigler Center New Working Paper Series No. 17, University of Chicago Booth School of Business.

Van Reenen, John, "Increasing Differences between Firms: Market Power and the MacroEconomy," in "Proceedings of the 2018 The Federal Reserve Bank of Kansas City Economic Policy Symposium: Changing Market Structures and Implications for Monetary Policy," Jackson Hole, WY, 2018.

Vives, Xavier, "Strategic Supply Function Competition With Private Information," Econometrica, 2011, 79 (6), 1919-1966.

Wessel, David, "Is Lack of Competition Strangling the U.S. Economy?," Harvard Business Review, March-April 2018.

White House, "Non-Compete Agreements: Analysis of the Usage, Potential Issues, and State Responses," 2016. https://obamawhitehouse.archives.gov/sites/default/files/noncompetes_report_final2.pdf.

Wilson, Daniel J., "Beggar Thy Neighbor? The In-state, Out-of-state, and Aggregate Effects of R\&D Tax Credits," Review of Economics and Statistics, 2009, 91 (2), 431-436.

Wollman, Thomas, "Stealth Consolidation: Evidence form an Amendment to the Hart-ScottRodino Act," American Economic Review: Insights, 2018. 


\section{Appendix - Proofs}

Lemma 2. On the balanced growth path, the growth rate of output $Y$ is the same as that of the aggregate productivity $Q$, as indicated by equation (11). The transition path of $Q_{t}$ is determined by innovations of neck-and-neck firms, which improve the productivity of workers employed in intermediate-good production, as summarized by

$$
\begin{aligned}
\ln Q_{t+\Delta t} & =\int_{0}^{1} x_{j t} \Delta t \ln \left(\lambda q_{j t}\right)+\left[\left(1-x_{j t} \Delta t\right)\right] \ln q_{j t} d j \Rightarrow \\
\ln Q_{t+\Delta t}-\ln Q_{t} & =\ln \lambda\left(2 x_{0 t} \mu_{0 t}\right) \Delta t+o(\Delta t) .
\end{aligned}
$$

Notice that any of the two firms in each neck-and-neck sector can innovate with the same flow rate $x_{0 t}$, hence, the multiplication by two. Dividing both sides of the expression by $\Delta t$, taking the limit as $t \rightarrow 0$, and calculating at the balanced growth path obtains the aggregate growth rate in equation (17).

Lemma 3. Taking the differences $\rho v_{1}-\rho v_{0}$ and $\rho v_{0}-\rho v_{-1}$ and rewriting we obtain

$$
\begin{aligned}
& 0=x_{0 t}^{2}+2(\rho+\delta) x_{0 t}-2\left(1-\frac{1}{\lambda}\right) \\
& 0=x_{-1 t}^{2}+2\left(\rho+\delta+x_{0 t}\right) x_{-1 t}-x_{0 t}^{2},
\end{aligned}
$$

which implies $x_{0 t}>x_{-1 t}$ and thus establishes Result 1 .

Total differentiation yields

$$
\frac{d x_{0}}{d \delta}=-\frac{x_{0}}{\left(x_{0}+\delta+\rho\right)}<0
$$

Likewise,

$$
\frac{d x_{-1}}{d \delta}=-\frac{x_{0}^{2}+x_{-1}(\delta+\rho)}{\left(\rho+\delta+x_{-1}+x_{0}\right)\left(x_{0}+\delta+\rho\right)}<0
$$

Comparison of the two derivatives implies

$$
\begin{aligned}
\left\|\frac{d x_{0}}{d \delta}\right\| & >\left\|\frac{d x_{-1}}{d \delta}\right\| \Leftrightarrow \\
\frac{x_{0}}{\left(x_{0}+\delta+\rho\right)} & >\frac{x_{0}^{2}+x_{-1}(\delta+\rho)}{\left(\rho+\delta+x_{-1}+x_{0}\right)\left(x_{0}+\delta+\rho\right)} \Leftrightarrow \\
\left(x_{0}-x_{-1}\right)(\delta+\rho)+x_{0} x_{-1} & >0,
\end{aligned}
$$


which is the case as $x_{0}>x_{-1}$. Thus we obtain Result 2:

$$
-1<\frac{d x_{0}}{d \delta}<\frac{d x_{-1}}{d \delta}<0
$$

Corollary 1. The implied distribution of gaps on the balanced growth path satisfies $\dot{\mu}=0$, i.e.,

$$
\begin{aligned}
0 & =\left(x_{-1}+\delta\right) \mu-2 x_{0} \mu_{0} \\
1 & =\mu_{0}+\mu \Rightarrow \\
0 & =\left(x_{-1}+\delta+2 x_{0}\right) \mu-2 x_{0} \Rightarrow \\
\mu & =\frac{2 x_{0}}{\left(x_{-1}+\delta+2 x_{0}\right)} .
\end{aligned}
$$

Totally differentiating the expression we have

$$
\begin{aligned}
0= & \left(d x_{-1}+d \delta+2 d x_{0}\right) \mu_{1}+\left(x_{-1}+\delta+2 x_{0}\right) d \mu_{1}-2 d x_{0} \Rightarrow \\
\frac{d \mu}{d \delta}= & {\left[-\left(\frac{d x_{-1}}{d \delta}+2 \frac{d x_{0}}{d \delta}+1\right) \mu_{1}+2 \frac{d x_{0}}{d \delta}\right]\left(x_{-1}+\delta+2 x_{0}\right)^{-1} } \\
= & {\left[\frac{(\rho+\delta)\left(2 x_{0}+\delta+\rho\right)+x_{0} x_{-1}}{\left(\rho+\delta+x_{-1}+x_{0}\right)\left(x_{0}+\delta+\rho\right)} \frac{2 x_{0}}{\left(x_{-1}+\delta+2 x_{0}\right)}-\frac{x_{-1}+\delta}{\left(x_{-1}+\delta+2 x_{0}\right)} \frac{2 x_{0}}{\left(x_{0}+\delta+\rho\right)}\right] \times } \\
& \left(x_{-1}+\delta+2 x_{0}\right)^{-1}<0 .
\end{aligned}
$$

Because $\left(x_{-1}+\delta+2 x_{0}\right)>0$, focus on $f(\mu)=\left[-\left(\frac{d x_{-1}}{d \delta}+2 \frac{d x_{0}}{d \delta}+1\right) \mu+2 \frac{d x_{0}}{d \delta}\right] \equiv A \mu-c$, where $A \equiv-\left(\frac{d x_{-1}}{d \delta}+2 \frac{d x_{0}}{d \delta}+1\right)$ and $c=-2 \frac{d x_{0}}{d \delta}$. Since $\mu \in[0,1], f(\mu) \geq 0$ iff $A \geq c$. However, we have

$$
\begin{aligned}
A & =-\left(\frac{d x_{-1}}{d \delta}+2 \frac{d x_{0}}{d \delta}+1\right) \\
& =-2 \frac{d x_{0}}{d \delta}-\left(1+\frac{d x_{-1}}{d \delta}\right) \\
& =c-\left(1+\frac{d x_{-1}}{d \delta}\right)<c
\end{aligned}
$$

because we have shown that $0>\frac{d x_{-1}}{d \delta}>-1$, which implies $\left(1+\frac{d x_{-1}}{d \delta}\right)>0$. Hence, $\frac{d \mu}{d \delta}<0$, implying that a decline in the rate of knowledge diffusion shifts the distribution to have more unleveled sectors. As shown in Akcigit and Ates (2019), in case of multiple steps, this result translates into a distributional shift to sectors with larger gap differences. 